\title{
Spiny-Cheek Crayfish, Faxonius limosus (Rafinesque, 1817), as an Alternative Food Source
}

\author{
Natalia Śmietana ${ }^{1}$, Remigiusz Panicz ${ }^{1, * \mathbb{D}}$, Małgorzata Sobczak ${ }^{1}$, Przemysław Śmietana ${ }^{2}$ and \\ Arkadiusz Nędzarek ${ }^{3}$ (i) \\ 1 Department of Meat Sciences, Faculty of Food Sciences and Fisheries, West Pomeranian University of \\ Technology in Szczecin, Kazimierza Królewicza Street 4, 71-550 Szczecin, Poland; \\ natalia.smietana@zut.edu.pl (N.Ś.); malgorzata.sobczak@zut.edu.pl (M.S.) \\ 2 Institute of Marine and Environmental Sciences, University of Szczecin, Adama Mickiewicza Street 18, \\ 70-383 Szczecin, Poland; przemyslaw.smietana@usz.edu.pl \\ 3 Department of Aquatic Bioengineering and Aquaculture, Faculty of Food Sciences and Fisheries, \\ West Pomeranian University of Technology in Szczecin, Kazimierza Królewicza Street 4, \\ 71-550 Szczecin, Poland; arkadiusz.nedzarek@zut.edu.pl \\ * Correspondence: rpanicz@zut.edu.pl; Tel.: +48-91-449-6664
}

Citation: Śmietana, N.; Panicz, R.; Sobczak, M.; Śmietana, P.; Nędzarek, A. Spiny-Cheek Crayfish, Faxonius limosus (Rafinesque, 1817), as an Alternative Food Source. Animals 2021, 11, 59. https://doi.org/ 10.3390/ani11010059

Received: 10 November 2020 Accepted: 28 December 2020 Published: 30 December 2020

Publisher's Note: MDPI stays neutral with regard to jurisdictional clai$\mathrm{ms}$ in published maps and institutional affiliations.

Copyright: (C) 2020 by the authors. Licensee MDPI, Basel, Switzerland. This article is an open access article distributed under the terms and conditions of the Creative Commons Attribution (CC BY) license (https:// creativecommons.org/licenses/by/ $4.0 /)$.
Simple Summary: Freshwater crayfish species are critical for both local communities and the modern food industry. The study characterised the meat of invasive spiny-cheek crayfish, analysing the yield, basic chemical composition, nutritional value, as well as culinary value. Crayfish meat has high nutritional parameters due to favourable fatty acid and amino acid profiles, as well as balanced mineral content. Crayfish meat is an alternative to livestock meat in the human diet and draws attention of the food industry to the processing of underutilised resources of high-quality aquatic species.

Abstract: The aim of the study was to present a comprehensive characterisation of crayfish meat, which is crucial to assess its potential usefulness in the food industry. To this end, we assessed the yield, basic chemical composition (protein, fat, minerals), nutritional value (amino acid and fatty acid profiles, essential amino acid index (EAAI), chemical score of essential amino acids (CS), hypocholesterolaemic/hypercholesterolaemic ratio $(\mathrm{h} / \mathrm{H})$, atherogenicity $(\mathrm{AI})$ and thrombogenicity (TI) indices), as well as culinary value (lab colour, texture, sensory characteristics, structure) of the meat of spiny-cheek crayfish (Faxonius limosus) $(n=226)$ from Lake Sominko (Poland) harvested in May-September 2017. Crayfish meat, especially that from the abdomen, was shown to have high nutritional parameters. It is lean $(0.26 \%$ of fat), with a favourable fatty acid profile and a very high quality of fat (PUFA (sum of polyunsaturated fatty acids):SFA (sum of saturated fatty acids), n-6/n-3, $\mathrm{h} / \mathrm{H}, \mathrm{AI}, \mathrm{TI}$ ) and protein (high CS and EAAI). It is also a better source of $\mathrm{Ca}, \mathrm{K}, \mathrm{Mg}, \mathrm{Na}$, $\mathrm{P}$, and $\mathrm{Cu}$ than meat from slaughter animals. Hence, crayfish meat can be an alternative to livestock meat in the human diet. Owing to its culinary value (delicateness, weak game flavour, and odour), it meets the requirements of the most demanding consumers, i.e., children and older people.

Keywords: aquatic food; freshwater crayfish; meat colour; nutrient requirements; sensory analysis; structure; texture

\section{Introduction}

In recent years, there has been an increase in interest in raw materials used to create new products to meet the growing demand of customers. The meat of freshwater crayfish is included in this category. It is consumed in various countries of Asia, North America, and Europe. In Europe, crayfish were found on tables from the Middle Ages to the 1920s. Later, the availability and popularity of crayfish for consumption decreased, e.g., owing to a rapid decline in the populations of local species caused by the emergence of crayfish 
plague in the second half of the 19th century. Hence, consumers started to consider crayfish as a very rare animal [1]. The second reason for the decrease in the population of European crayfish species was the introduction of spiny-cheek crayfish (Orconectes [Faxonius] limosus [Rafinesque, 1817]), originating in North America, and signal crayfish (Pacifastacus leniusculus) into water reservoirs at the end of the 20th century [2]. The two species, compared with native species, have superior reproductive performance, tolerance to environmental conditions, and resistance to diseases [2]. Owing to these characteristics, the species have spread in the natural environment and outnumbered indigenous species [2]. Spiny-cheek crayfish are currently widespread in multiple European countries [3,4]. Their presence has been recorded in Germany, Poland, the Czech Republic, Netherlands, Luxembourg, France, United Kingdom, Russia, Slovakia, Romania, Serbia, Croatia, Switzerland, Austria, Belgium, Spain, Belarus, Latvia, Lithuania, Hungary, and Italy [3], and since 2008 in Estonia [4]. In all those countries, spiny-cheek crayfish poses a threat to the indigenous crayfish species. The population size of spiny-cheek crayfish is growing steadily and depends on the location and type of water reservoir. In Poland, 57 sites of occurrence of the species were recorded in 1959 compared with 1383 sites recorded in 2004 [5]. In Nottinghamshire (UK), spiny-cheek crayfish colonised 16 ha of Attenborough Lake within 4 to 5 years [6]. In the German Lake Grosser Vätersee, the species accounts for up to $49 \%$ of the biomass of macroinvertebrates, which is equivalent to $35 \%$ and $81 \%$ of the biomass of herbivorous and predatory fish, respectively [7]. In Lake Varese, the population of this species is estimated at 6.4-16.7 individuals $\mathrm{m}^{-2}$ of the reservoir, depending on the site [8].

Rebuilding the populations of indigenous crayfish could be aided by harvesting invasive species that may be a source of edible and non-edible raw material [9-12]. The effectiveness (yield) of these catches would be affected by the type of water reservoir, season of the year, as well as method and gear used for the catches $[8,13]$. However, use of spinycheek crayfish in the food industry would only be possible once studies assessing the yield and properties of crayfish meat have been conducted. The available literature includes studies of the nutritional value of the meat of different crayfish species (Procambarus clarkii, Astacus leptodactylus, Astacus astacus, Cherax quadricarinatus) and use of their inedible parts (exoskeleton) and edible parts (meat and meat protein preparations) in the food industry $[10,14,15]$. Crayfish meat has a high nutritional value, i.e., high protein content $(12.9-17.8 \%)$ with a relatively low fat content $(0.14-1.69 \%)$ [16-18] and a desired fatty acid composition and low cholesterol content (75.9-81.2 $\mathrm{mg} \mathrm{g}^{-1}$ ) [17]. However, there are no detailed data comprehensively describing the quality and nutritional value of the meat of spiny-cheek crayfish. Studies by Stanek et al. [19-21] only concerned the characteristics of the abdomen meat fat of this crustacean species. This information is insufficient to estimate the usefulness of this raw material in the food industry. Therefore, the aim of this study was to assess the nutritional value (chemical composition, amino acid and fatty acid profiles, element content) and quality parameters ( $\mathrm{pH}$, colour, texture, and sensory properties) of the meat of spiny-cheek crayfish.

\section{Materials and Methods}

\subsection{Crayfish Sampling and Basic Characteristics}

Live whole spiny-cheek crayfish individuals $(n=226)$ were caught by free diving from Lake Sominko (Poland), (54 $4^{\circ} 47^{\prime \prime}$ N 17 $52^{\prime} 48^{\prime \prime}$ E) in May-September of 2017. Immediately after sampling. the crayfish were placed in a tank filled with water and transported to the laboratory of the Department of Meat Sciences (ZUT in Szczecin, Poland). Upon arrival, individuals were kept at $4{ }^{\circ} \mathrm{C}$ overnight and subsequently euthanised and weighed using an electronic balance (PS6100.R2.M, Radwag, Radom, Poland). Individuals were dissected, and the abdomen and a chela, including the meat and hard parts thereof, were weighed. The yields (\%) of the meat and hard parts were calculated using the following formulae:

$$
\text { Yield of hard parts ( } \% \text { of body part })=\frac{\text { weight of hard parts }}{\text { weight of body parts }} \times 100 \%
$$




$$
\begin{gathered}
\text { Yield of meat }(\% \text { of body part })=\frac{\text { weight of meat }}{\text { weight of body parts }} \times 100 \% \\
\text { Yield of meat }(\% \text { of body })=\frac{\text { weight of meat }}{\text { weight of body }} \times 100 \%
\end{gathered}
$$

Ethics approval was obtained from the ethics committee of the Faculty of Food Sciences and Fisheries (ZUT in Szczecin, Poland, number 517-08-026-7724/17). We adhered to the "Guidelines for the treatment of animals in behavioural research and teaching" published in Animal Behaviour [22].

\subsection{Chemical Analyses}

The chemical composition of minced abdomen and chelae meat $(n=32)$ was determined according to AOAC (Association of Official Analytical Chemists) procedures [23]. Moisture was obtained after drying samples in an oven at $105^{\circ} \mathrm{C}$ for $24 \mathrm{~h}$, while ash content was determined after incineration at $550{ }^{\circ} \mathrm{C}$ for $6 \mathrm{~h}$. To assess the level of crude protein in crayfish meat, the content of $\mathrm{N}$ was first assessed by digesting $0.500 \pm 0.01 \mathrm{~g}$ of meat samples in the mixture of 95\% sulfuric acid (Chempur, Piekary Ślaskie, Poland) and 30\% hydrogen peroxide (Chempur, Piekary Ślaskie, Poland) in equal volumes of $10 \mathrm{~mL}$ each, together with a catalyst-Kjeldahl tablets (MERCK KGaA, Darmstadt, Germany). A digestion step was performed using Heating Digester DK6 and DK8 (VELP Scientifica, Usmate Velate, Italy) following the thermal profile of $30 \mathrm{~min}$ at $180{ }^{\circ} \mathrm{C}, 30 \mathrm{~min}$ at $280{ }^{\circ} \mathrm{C}$, and $30 \mathrm{~min}$ at $380^{\circ} \mathrm{C}$. Subsequently, crude protein was measured by determining the nitrogen content $(\mathrm{N} \times 6.25)$ according to the Kjeldahl method, using a Tecator Kjeltec 2100 distillation unit (FOSS Analytical Co., Ltd., Jiangsu, China). Crude lipid was determined gravimetrically, after Soxhlet lipid extraction on a Tecator Soxtec System HT 1043 (FOSS Analytical Co., Ltd., Jiangsu, China). The procedure of lipid extraction was performed according to the default settings recommended by the equipment vendor, i.e., at $90{ }^{\circ} \mathrm{C}$ in the presence of petroleum ether 40/60 pure p.a. (Chempur, Piekary Ślaskie, Poland). The fatty acid profiles in abdomen meat samples $(n=50)$ were quantified using gas chromatography $(\mathrm{GC})$ with a flame ionisation detector (FID). Briefly, fatty acids were determined as fatty acid methyl esters (FAME), and individual FAME were identified by comparing their retention times with those of pure standards. Analyses were carried out in triplicate on an Agilent 6890N Network Gas Chromatograph (Agilent Technologies; Palo Alto, CA, USA) equipped with a 7683 automatic liquid sampler and flame ionisation detectors. The amino acid profile of proteins $(n=20)$ in the abdomen and chelae meat samples was determined by High Performance Liquid Chromatography (HPLC) using an AAA 400 amino acid analyser (Ingos, Prague, Czech Republic). The chromatograms were analysed using the CHROMuLAN V 0.88 program (PiKRON, Prague, Czech Republic) by comparison with the standard chromatogram, taking into account dilution and weight. All analyses were performed in triplicate. Energy value was calculated using the relative percentage of each nutrient (protein and fat) which was multiplied by the correction factors, $4 \mathrm{kcal} \mathrm{g}^{-1}\left(17 \mathrm{~kJ} \mathrm{~g}^{-1}\right)$ and $9 \mathrm{kcal} \mathrm{g}^{-1}\left(37 \mathrm{~kJ} \mathrm{~g}^{-1}\right)$ for protein and fat, respectively, as described in Regulation (EU) No. 1169/2011 [24].

Protein quality was described by the chemical score (CS) of essential amino acids (EAA) and the essential amino acids index (EAAI). The CS was calculated in relation to a reference scoring pattern suggested by FAO/WHO/UNU [25] according to the following equation:

$$
\mathrm{CS}=\frac{\mathrm{g} \text { EAA } \text { in tested protein }}{\mathrm{g} \text { EAA } \text { in pattern protein }} \times 100
$$

The essential amino acids index (EAAI) was calculated according to the equation described by Shahidi and Synowiecki [26]:

$$
\text { EAAI }=100 \times \sqrt[n]{\frac{a}{a_{p}} \times \frac{b}{b_{p}} \times \ldots \times \frac{i}{i_{p}}}
$$


where $a, b, \ldots, i-c o n t e n t$ of histidine, isoleucine, leucine, lysine, SAA (sulphur amino acids—sum of methionine and cysteine), AAA (aromatic amino acids—sum of phenylalanine, tyrosine, and tryptophan), threonine and valine in sample, $a_{p}, b_{p}, \ldots, i_{p}-c o n t e n t ~ o f$ histidine, isoleucine, leucine, lysine, SAA (sulphur amino acids-sum of methionine and cysteine), AAA (aromatic amino acids-sum of phenylalanine, tyrosine, and tryptophan), threonine and valine in protein standard [25], n-number of amino acids.

Fat quality was described by the following factors: SFA (sum of saturated fatty acids), MUFA (sum of monounsaturated fatty acids), PUFA (sum of polyunsaturated fatty acids), $\mathrm{h} / \mathrm{H}$ (hypocholesterolaemic/hypercholesterolaemic ratio), AI (index of atherogenicity), and TI (index of thrombogenicity). These factors were calculated using the fallowing equations [27-29]:

$$
\mathrm{SFA}=(\mathrm{C} 12: 0+\mathrm{C} 14: 0+\mathrm{C} 15: 0+\mathrm{C} 16: 0+\mathrm{C} 17: 0+\mathrm{C} 18: 0+\mathrm{C} 20: 0+\mathrm{C} 21: 0+\mathrm{C} 22: 0)
$$

$$
\text { MUFA }=(C 16: 1 n 7+C 17: 1 n 7+C 18: 1 n 9 t+C 18: 1 n 9 c+C 20: 1 n 5+C 20: 1 n 9)
$$

$$
\begin{aligned}
& \text { PUFA }=(C 18: 2 n 6 t+C 18: 2 n 6 c+C 18: 3 n 3+C 20: 2 n 6+C 20: 3 n 3+C 20: 3 n 6+C 20: 4 n 6+C 20: 5 n 3+C 22: 6 n 3) \\
& \mathrm{h} / \mathrm{H}=\Sigma(\mathrm{C} 18: 1 \mathrm{n} \text { 9, C18:1n 7, C18:2n 6, C18:3n 6, C18:3n 3, C20:3n 6,C20:4n 6, } \\
& \text { C20:5n 3, C22:4n 6, C22:5n 3, C22:6n 3)/ }(\text { (C14:0, C16:0) } \\
& \mathrm{AI}=(\mathrm{C} 12: 0+4 \times \mathrm{C} 14: 0+\mathrm{C} 16: 0) /((\mathrm{n}-6) \mathrm{PUFA}+(\mathrm{n}-3) \mathrm{PUFA}+\text { MUFA }) \\
& \mathrm{TI}=(\mathrm{C} 14: 0+\mathrm{C} 16: 0+\mathrm{C} 18: 0) /(0.5 \times \text { MUFA }+0.5 \times(\mathrm{n}-6) \mathrm{PUFA}+3.0 \times(\mathrm{n}-3) \mathrm{PUFA}+(\mathrm{n}-3) \mathrm{PUFA} /(\mathrm{n}-6) \mathrm{PUFA})
\end{aligned}
$$

\subsection{Elemental Analysis}

The abdomen and chelae meat samples ( $n=24$, each) of spiny-cheek crayfish were dissolved as described by Mistri et al. [30]. Samples of $0.8 \pm 0.1 \mathrm{~g}$ (wet weight) were digested in $10 \mathrm{~mL}$ of concentrated ultrapure $\mathrm{HNO}_{3}$ (Merck, Darmstadt, Germany) in a Speedwave Xpert high-pressure microwave mineraliser (Berghof, Eningen, Germany). The DAK-100 reaction vessels used were made of TFM ${ }^{\text {TM }}$-PTFE (second generation of polytetrafluorethylene), and the digestion conditions were as follows: power- $2000 \mathrm{~W}$, hold time $-25 \mathrm{~min}$, and temperature $-200^{\circ} \mathrm{C}$. After cooling, samples were transferred into volumetric flasks $(25 \mathrm{~mL})$ and diluted to the mark with deionised water $(18.2 \mathrm{M} \Omega$ ). Element measurements in crayfish tissues were carried out with a Hitachi ZA3000 Series Polarised Zeeman Atomic Absorption Spectrometer (Hitachi High-Technologies Corporation, Tokyo, Japan) equipped with a Zeeman background correction system. Ca, K, Na, and $\mathrm{Mg}$ were measured using flame atomic absorption spectroscopy (FAAS) in an airacetylene flame. $\mathrm{Al}, \mathrm{Cd}, \mathrm{Cu}, \mathrm{Fe}, \mathrm{Pb}$, and $\mathrm{Zn}$ were measured using graphite furnace atomic absorption spectroscopy (GFAAS). Radiation sources for elements were hollow-cathode lamps (HCL, Hitachi High-Technologies Corporation, Tokyo, Japan) at the appropriate wavelengths (in nm): 309.3 (for Al); 422.7 (for Ca); 228.8 (for Cd); 324.8 (for Cu); 248.3 (for $\mathrm{Fe}$ ); 766.5 (for K); 285.2 (for Mg); 589.0 (for $\mathrm{Na}$ ); 283.3 (for $\mathrm{Pb}$ ); 213.9 (for Zn). The following matrix modifiers were also used: palladium $\left(0.2 \% \mathrm{Pd}\right.$ in $5 \% \mathrm{HNO}_{3}$, SIGMATIK, Wroclaw, Poland); $\mathrm{Mg}\left(\mathrm{NO}_{3}\right)_{2}$ and $\mathrm{NH}_{4} \mathrm{H}_{2} \mathrm{PO}_{4}$ (both $1000 \mathrm{mg} \mathrm{L}^{-1}$, Merck, Darmstadt, Germany), along with the caesium chloride-lanthanum chloride buffer solution acc. to Schinkel for atomic absorption spectroscopy $\left(10 \mathrm{~g} \mathrm{~L}^{-1} \mathrm{CsCl}\right.$ and $100 \mathrm{~g} \mathrm{~L}^{-1} \mathrm{La}, \mathrm{MERCK}$, Darmstadt, Germany). Phosphorus (P) was quantified colorimetrically in the same sample solutions as the other elements. The employed method, described by Jastrzęska [31], used ammonium molybdate and ascorbic acid as reducers, forming molybdenum blue. Absorbance at $\lambda=882 \mathrm{~nm}$ was measured on a UV-VIS spectrophotometer Spectroquant Pharo 300 (Merck, Darmstadt, Germany).

Calibration curves were established using certified standard solutions $\left(1000 \mathrm{mg} \mathrm{L}^{-1}\right)$ from Scharlau (Barcelona, Spain) for $\mathrm{Mg}, \mathrm{Ca}, \mathrm{K}, \mathrm{Na}$, and Fe, and from Merck (Darmstadt, Germany) for $\mathrm{Al}, \mathrm{Cd}, \mathrm{Cu}, \mathrm{P}, \mathrm{Pb}$, and $\mathrm{Zn}$. The range of standard concentrations included only the linear character of the calibration curve (the R-factor, determined by the spectrophotometer program, was always $>0.9955)$. Limits of Quantification (LOQ) were as follows: 


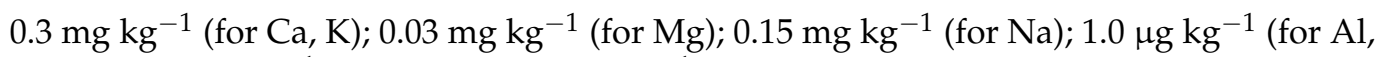
$\mathrm{Cd}, \mathrm{Pb}$ ); $1.5 \mu \mathrm{g} \mathrm{kg}^{-1}$ (for $\mathrm{Cu}, \mathrm{Fe}$ ); $0.2 \mu \mathrm{g} \mathrm{kg}^{-1}$ (for $\mathrm{Zn}$ ). The obtained results were assessed for accuracy and precision using certified reference material of Fish Muscle ERM BB422 (European Reference Materials, European Commission-Joint Research Centre, Institute for Reference Materials and Measurements, Geel, Belgium). The recovery of elements was within $95-105 \%$ and the precision for reference material was $1.3-11.4 \%$. See Table S1 for comprehensive data analysis.

\subsection{Assessment of Muscle Structure}

Samples $(5 \times 5 \times 5 \mathrm{~mm})$ of raw chelae and abdomen meat $(n=20)$ were fixed for $12 \mathrm{~h}$ in Sannomiya solution, dehydrated using alcohol, and saturated in intermediate solutions (benzene, benzene: paraffin). Then, samples were embedded in paraffin blocks, trimmed, sectioned (10 $\pm 1 \mu \mathrm{m}$, Rotary Microtome MPS-2, Opta-Tech, Warsaw, Poland), stained with haematoxylin and eosin, and mounted on slides with Canadian lotion [32]. For each sample, three pieces of specimen were prepared, randomly selected, and examined by two members of the laboratory using an Eclipse E600 microscope (Nikon, Nikon, Japan) with a 100× objective. Specimens were screened for fibre cross-section area (CSA), fibre girth, horizontal $(\mathrm{H})$ and vertical (V) diameter of fibre, and thickness of endomysium using the ROI (region of interest) tool in the NIS-Elements Basic Research software (Nikon Instruments Europe B.V, Warsaw, Poland), (Figure 1). Additionally, fibre shape was calculated as the H:V diameter ratio.

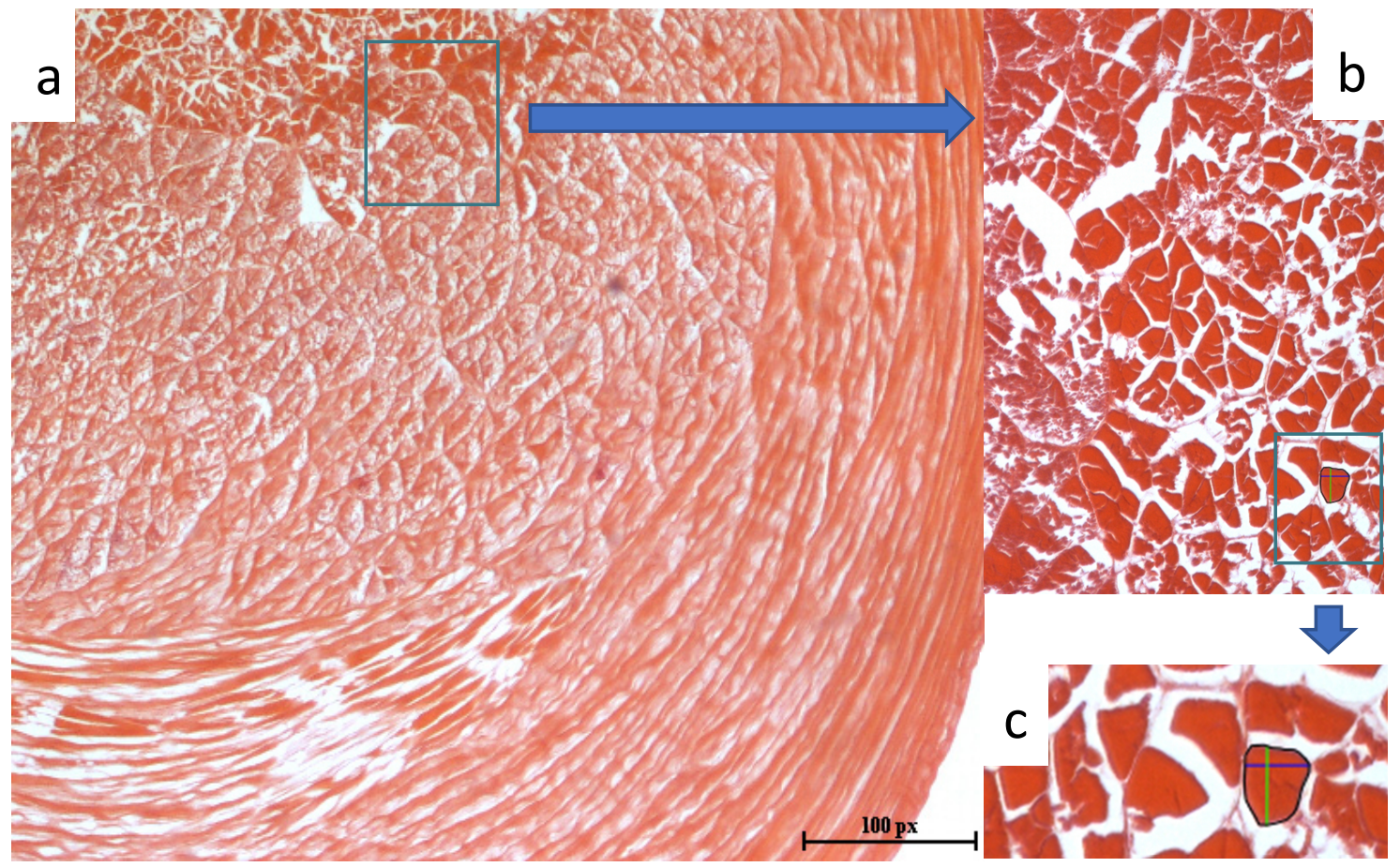

Figure 1. Cross-section of the abdomen meat (a), structure elements of muscles (b) and fibre cross-section area, fibre girth (black line), horizontal (blue line) and vertical (green line) diameter (c).

\section{5. $\mathrm{pH}$ and Colour}

$\mathrm{pH}$ was measured in quadruplicates for each sample $(n=20)$ of raw meat of chelae and abdomen. The measurement was done using a portable pH meter (CP-411, Elmetron, Zabrze, Poland) with a glass penetrating electrode. Before the analysis, the $\mathrm{pH}$ meter was calibrated using standard phosphate buffers ( $\mathrm{pH} 4.00$ and 7.00). Between measurements, the electrode was rinsed thoroughly with distilled water. The colour of raw meat of chelae and abdomen samples $(n=20)$ was assessed using a NR 20XE Precision Colorimeter (Shenzhen 3NH Technology Co., Ltd., Shenzhen, China) with $\varphi 20 \mathrm{~mm}$ extended aperture. 
$\mathrm{L}^{*}$ (lightness), $\mathrm{a}^{*}$ (redness), and $\mathrm{b}^{*}$ (yellowness) were obtained automatically after a light shot had been discharged perpendicularly to the surface of abdomen and chelae meat. Measurements were done in triplicates. Whiteness index (WI) and chromaticity (C) were calculated using following equations:

$$
\begin{gathered}
W I=100-\left[(100-L)^{2}+a^{2}+b^{2}\right]^{0.5} \\
C=\left(a^{2}+b^{2}\right)^{0.5}
\end{gathered}
$$

\subsection{Texture}

The texture of abdomen meat boiled for $4 \min (n=20)$ was measured in quintuplicate with Instron 1140 (Stable Instron, Bucks, UK) using a double compression test [33]. Briefly, a $120 \mathrm{~mm}^{2}$ plate compressed the sample twice to $80 \%$ of their original height, and parameters, such as hardness $(\mathrm{N})$, cohesiveness $(-)$, springiness $(\mathrm{cm})$, and chewiness $(\mathrm{N} \times \mathrm{cm})$, were measured. The crosshead speed was $50 \mathrm{~mm} \mathrm{~min}^{-1}$.

\subsection{Sensory Analysis}

Sensory evaluation of abdomen meat boiled for $4 \min (n=20)$ was conducted by a trained team, composed of four members [34]. Texture characteristics (springiness, cohesiveness, hardness, tenderness, moisture, juiciness, perceptibility of connective tissue, chewiness, fattiness, astringency), intensity of odour, and taste descriptors were evaluated. Intensity of these features was rated using a 5-point scale, where 1 point corresponded to the lowest and 5 points to the highest intensity.

\subsection{Statistical Analysis}

Data were analysed using STATISTICA for Windows (version 13.1, Krakow, Poland). The data were subjected to a two-way analysis of variance (ANOVA) and Tukey's test to compare sample means. The significance level for Tukey's test was 0.05 .

\section{Results and Discussion}

\subsection{Yield of Spiny-Cheek Crayfish Meat}

Crayfish meat is considered to be a particular type of raw material due to its sensory properties, method of preparation, availability, and origin. Although it is currently not widely used for food purposes, it can become an alternative source of animal raw material in the near future. However, full use of crayfish meat by the food sector will only be possible once it has been thoroughly characterised. Our study showed that the percentage yield of meat in the abdomen and chelae in relation to the total body mass of crayfish were $8.67 \%$ and $2.69 \%$, respectively (Table 1 ).

Table 1. Yield of meat and hard parts in the abdomen and chelae of F. limosus.

\begin{tabular}{cccc}
\hline \multirow{2}{*}{ Yield } & \multicolumn{2}{c}{ Body Part } & \multirow{2}{*}{$\begin{array}{c}\text { Significance } \\
\text { of Influence }\end{array}$} \\
\cline { 2 - 4 } & Abdomen & Chelae & $*$ \\
\hline Yield of hard parts (\% of body part) & $62.79^{\mathrm{a}} \pm 0.301$ & $87.07^{\mathrm{b}} \pm 9.922$ & $*$ \\
\hline Yield of meat (\% of body part) & $37.21^{\mathrm{a}} \pm 1.899$ & $12.93^{\mathrm{b}} \pm 3.962$ & $*$ \\
\hline Yield of meat (\% of body) & $8.67^{\mathrm{a}} \pm 0.844$ & $2.69^{\mathrm{b}} \pm 1.328$ & $*$ \\
\hline
\end{tabular}

Values are expressed as mean \pm standard deviation (SD), ${ }^{\mathrm{a}, \mathrm{b}}$-values in rows with different index differ significantly $(p \leq 0.05)$, significance of influence: ${ }^{*} p \leq 0.05 ; * * 0.01$.

A higher yield of abdomen meat compared with that of the chelae was also demonstrated by a study by Berber and Balık [35] in A. leptodactylus, but in both cases, yield was higher (12.98\% and $3.47 \%$, respectively) than in our study. In turn, Thompson et al. [18] showed a more than doubled (24\%) percentage yield of abdomen meat for red chelae crayfish, Cherax quadricarinatus, stocked into earthen ponds. The percentage of muscle and 
hard parts varies depending on the species, population, age, and degree of exoskeleton mineralisation. For example, P. leniusculus has a much more mineralised exoskeleton compared with $A$. leptodactylus. Consequently, with a comparable share of abdomen muscle $(13.7 \%$ vs. $12.6 \%)$, exoskeleton mineralisation has a significant impact on the actual yields of abdomen meat in both species ( $7.5 \mathrm{~g}$ vs. $3.3 \mathrm{~g}$ ) [36]. The degree of mineralisation of individual body parts of crayfish is a result of the function played by the body part, which is clearly demonstrated by the significantly higher $(p \leq 0.05)$ share of shell in chelae than in the abdomen reported in the study [37]. The thick armour of chelipeds and chelae allows crayfish to function more effectively in the environment; however, it complicates meat recovery from that body part. Appropriate technology is necessary for this purpose, as manual meat removal from chelae is usually economically inviable and involves a microbiological risk. For example, the industrial extraction of meat from chelae uses two-phase separation preceded by the crushing of chelae [38].

\subsection{Nutritional Value of Spiny-Cheek Crayfish Meat}

Chemical analysis did not reveal any significant differences $(p>0.05)$ in the content of protein, fat, ash, dry matter, and energy between abdomen and chelae meat (Table 2). Protein content in the meat of the abdomen $(18.23 \pm 0.732)$ and chelae $(18.83 \pm 1.476)$ of F. limosus was comparable to that in other crayfish species [19,39], marine and freshwater fish [40], and livestock [41,42]. Based on the results of this study and studies by other authors $[19,21,43]$, the fat content in the meat of spiny-cheek crayfish is $0.26 \%$ and $0.24-1.35 \%$, respectively, which allows considering this meat as lean. A similar amount of fat is found in the meat of lean fish $(<2 \%)$ and in that of other crustaceans $[43,44]$. For example, for red swamp crayfish (Procambarus clarkii), El-Kholie et al. [45] reported approximately $1.99 \%$ of crude fat. Due to the low fat content, the energy value of the abdomen and chelae meat of

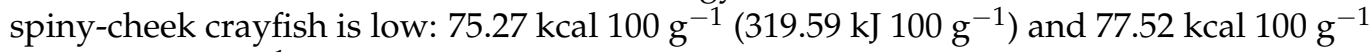

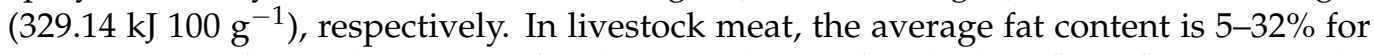
pigs, $3.3-7.6 \%$ for cattle, $2.7-12 \%$ for sheep, and $1-9 \%$ for chickens $[42,46]$. In game, the values are $2.82 \%, 1.6 \%, 1.9 \%$, and $1.3 \%$ for wild boar, roe deer, red deer, and moose, respectively [47]. Moreover, the energy value of livestock meat is higher than that of crayfish meat. For example, the energy value per $100 \mathrm{~g}$ is $115-146 \mathrm{kcal}$ or $455-716 \mathrm{~kJ}$ for cattle, 134-353 kcal or 461-784 kJ for pig, $122 \mathrm{kcal}$ or 473-767 kJ for sheep [41,42,48], 109-178 kcal for chicken, 106-136 kcal for turkey, and approximately $130 \mathrm{kcal}$ for duck [41]. Based on the above list, it appears that in terms of fat and calorie content, the meat of spiny-cheek crayfish may be an alternative to livestock meat for consumers.

Table 2. Proximate composition of abdomen and chelae muscles of F. limosus.

\begin{tabular}{cccc}
\hline $\begin{array}{c}\text { Component } \\
\text { (\% of Wet Weight) }\end{array}$ & Abdomen & Chelae & $\begin{array}{c}\text { Significance } \\
\text { of Influence }\end{array}$ \\
\hline Crude protein $(\%)$ & $18.23 \pm 0.732$ & $18.83 \pm 1.476$ & n.s. \\
\hline Crude fat $(\%)$ & $0.26 \pm 0.024$ & $0.26 \pm 0.033$ & n.s. \\
\hline Ash $(\%)$ & $1.59 \pm 0.357$ & $2.00 \pm 0.810$ & n.s. \\
\hline Dry matter $(\%)$ & $20.28 \pm 1.167$ & $21.66 \pm 1.755$ & n.s. \\
\hline $\begin{array}{c}\text { Energy value }(\mathrm{kcal} / 100 \mathrm{~g}) \\
(\mathrm{kJ} / 100 \mathrm{~g})\end{array}$ & $75.27 \pm 3.102$ & $77.52 \pm 6.057$ & n.s. \\
\hline
\end{tabular}

Analysis of the obtained data showed significant differences in the mineral content of the abdomen and chelae meat of spiny-cheek crayfish. The muscle of the abdomen had a significantly higher content of $\mathrm{K}, \mathrm{P}(p \leq 0.01)$ and $\mathrm{Cd}, \mathrm{Pb}(p \leq 0.05)$, and it had a significantly lower amount of $\mathrm{Ca}, \mathrm{Mg}, \mathrm{Na}, \mathrm{Fe}$, and $\mathrm{Zn}(p \leq 0.01)$ as well as $\mathrm{Al}$ and $\mathrm{Cu}(p \leq 0.05)$ than that of chelae (Table 3$)$. Difference in the observed contents of the elements reflects the composition of the diet but also the function of muscles located in 
the abdomen and chelae [49-51]. When comparing the mineral content of the meat of spiny-cheek crayfish with that of other animal species, it can be demonstrated that a similar $\mathrm{Ca}, \mathrm{K}$, and $\mathrm{Zn}$ content is present in the meat of Chinese mitten crab (Eriocheir sinensis) [52]. Lower amounts of $\mathrm{Ca}, \mathrm{K}, \mathrm{Mg}, \mathrm{Na}, \mathrm{P}$, and $\mathrm{Cu}$ and higher amounts of $\mathrm{Fe}$ and $\mathrm{Zn}$ have been recorded in the meat of cattle, sheep, pig [42,48], and chicken [53]. According to EU health claims legislation [24], beef, lamb, and pork can be classified as rich sources of several nutrients. Beef is a rich source of $\mathrm{Zn}$ and a source of $\mathrm{Fe}, \mathrm{K}$, and P; lamb is a rich source of $\mathrm{Zn}$ and a source of $\mathrm{K}$ and $\mathrm{P}$; whereas pork is a source of $\mathrm{Fe}, \mathrm{Se}, \mathrm{K}$, and $P$ [42]. Our study showed that the meat of spiny-cheek crayfish is an even better source of $\mathrm{Ca}, \mathrm{K}, \mathrm{Mg}, \mathrm{Na}, \mathrm{P}$, and $\mathrm{Cu}$ than livestock meat. The levels of $\mathrm{Pb}$ and $\mathrm{Cd}$ in the meat of the abdomen and chelae did not exceed the established food safety level of $0.50 \mathrm{\mu g} \mathrm{g}^{-1}$. The higher concentration of $\mathrm{Cd}$ and $\mathrm{Pb}$ in the meat of the abdomen compared with that of chelae might be explained by different biological and natural factors, as shown for green crab (Carcinus maenas). The accumulation rate depends on ion concentrations, hydration level, and also the volume of tissues, which can be interpreted as condition $[54,55]$. In our case, the level of dry matter (hydration) was similar for the investigated meat samples, but abdomen meat with its higher yield presumably had a higher capacity to accumulate heavy metals. Our study showed that the abdomen and chelae meat of spiny-cheek crayfish is toxicologically safe and can be a good source of macro- and microelements in human nutrition. The consumption of $100 \mathrm{~g}$ of chelae meat covers $103.7 \%, 54.8 \%$, and $45.1 \%$ of the consumer's daily demand for $\mathrm{Zn}, \mathrm{Ca}$, and $\mathrm{P}$, respectively. The consumption of $100 \mathrm{~g}$ of abdomen meat mostly covers the demand for P (49.93\%), Zn (17.08\%), and K (11.75\%) (Table 3). In comparison, the consumption of $100 \mathrm{~g}$ of beef covers $9 \%, 22 \%$, and $30 \%$ of the demand for $\mathrm{K}, \mathrm{P}$, and $\mathrm{Zn}$, respectively [48].

The nutritional value of raw materials and food products, in addition to the basic nutrients and minerals, is also determined by the nutritional value of protein based on its amino acid composition. Our study showed that the meat of the abdomen and chelae has a comparable amino acid composition. The exceptions were the significantly $(p \leq 0.01)$ higher levels of arginine and glycine in abdomen muscles and of alanine and proline in chelae muscles (Table 4). 
Table 3. Content of elements in the abdomen and chelae meat of $F$. limosus, and percentage of elements covered with $100 \mathrm{~g}$ of abdomen and chelae meat.

\begin{tabular}{|c|c|c|c|c|c|c|c|}
\hline \multirow[t]{2}{*}{ Elements } & \multicolumn{2}{|c|}{ Content of Elements } & \multirow{2}{*}{$\begin{array}{l}\text { Significance } \\
\text { of Influence }\end{array}$} & \multicolumn{2}{|c|}{$\begin{array}{c}\% \text { of Elements } \\
\text { Covered with } 100 \mathrm{~g} \text { of Meat }\end{array}$} & \multirow{2}{*}{$\begin{array}{l}\text { Dietary Recommendations } \\
\text { UL/AI A/PRI }{ }^{B} / \text { MAL }^{\prime}\end{array}$} & \multirow[t]{2}{*}{ References } \\
\hline & Abdomen & Chelae & & Abdomen & Chelae & & \\
\hline \multicolumn{8}{|l|}{ Macroelements } \\
\hline $\mathrm{Ca}\left(\mathrm{mg} \mathrm{kg}^{-1}\right)$ & $271.4^{\mathrm{a}} \pm 88.98$ & $13701^{\mathrm{b}} \pm 4951$ & $* *$ & 1.09 & 54.80 & $2500 \mathrm{mg} \mathrm{day}^{-1}$ & [56] \\
\hline $\mathrm{K}\left(\mathrm{mg} \mathrm{kg}^{-1}\right)$ & $4111^{\mathrm{a}} \pm 368.3$ & $3460^{\mathrm{a}} \pm 166.0$ & $* *$ & 11.75 & 9.89 & $3500 \mathrm{mg} \mathrm{day}^{-1 \mathrm{~A}}$ & [57] \\
\hline $\operatorname{Mg}\left(\mathrm{mg} \mathrm{kg}^{-1}\right)$ & $323.4^{\mathrm{a}} \pm 36.662$ & $405.4^{\mathrm{b}} \pm 32.545$ & $* *$ & $9.24-10.78$ & $11.58-13.51$ & $\mathrm{o}^{\top} 350 / \$ 300 \mathrm{mg} \mathrm{day}^{-1 \mathrm{~A}}$ & [58] \\
\hline $\mathrm{Na}\left(\mathrm{mg} \mathrm{kg}^{-1}\right)$ & $890^{a} \pm 139.911$ & $1319^{b} \pm 184.59$ & $* *$ & 5.93 & 8.79 & $1500 \mathrm{mg} \mathrm{day}^{-1 \mathrm{~A}}$ & [59] \\
\hline \multicolumn{8}{|l|}{ Essential elements } \\
\hline $\mathrm{Al}\left(\mathrm{mg} \mathrm{kg}^{-1}\right)$ & $25.17^{\mathrm{a}} \pm 3.915$ & $34.69^{b} \pm 4.654$ & * & 2.57 & 3.54 & $1.4 \mathrm{mg} \mathrm{bw}^{-1} \mathrm{day}^{-1} / 98 \mathrm{mg} \mathrm{day}^{-1+} /$ & [61] \\
\hline $\mathrm{Cu}\left(\mathrm{mg} \mathrm{kg}^{-1}\right)$ & $3.01^{\mathrm{a}} \pm 0.258$ & $3.55^{b} \pm 0.265$ & * & 6.02 & 7.10 & $5.0 \mathrm{mg} \mathrm{day}{ }^{-1}$ & [56] \\
\hline $\mathrm{Fe}\left(\mathrm{mg} \mathrm{kg}^{-1}\right)$ & $3.76^{\mathrm{a}} \pm 0.778$ & $5.37^{\mathrm{b}} \pm 0.734$ & $* *$ & $4.18-3.76(2.51)$ & $5.97-5.37(3.58)$ & 9-10 mg day ${ }^{-1 \mathrm{~B}}\left(15 \mathrm{mg} \mathrm{day}^{-1 \mathrm{~B}, \mathrm{C}}\right)$ & {$[62]$} \\
\hline $\mathrm{Zn}\left(\mathrm{mg} \mathrm{kg}^{-1}\right)$ & $13.66^{\mathrm{a}} \pm 2.131$ & $82.96^{\mathrm{b}} \pm 14.661$ & $* *$ & 17.08 & 103.7 & $25 \mathrm{mg} \mathrm{day}{ }^{-1}$ & {$[56]$} \\
\hline \multicolumn{8}{|c|}{ Nonessential elements } \\
\hline $\mathrm{Cd}\left(\mu \mathrm{g} \mathrm{kg}^{-1}\right)$ & $16.54^{\mathrm{a}} \pm 0.602$ & $13.20^{\mathrm{b}} \pm 1.374$ & * & 0.33 & 0.26 & $0.5 \mathrm{mg} \mathrm{kg}^{-1} \mathrm{ww} \ddagger$ & \multirow{2}{*}{ [63] } \\
\hline $\mathrm{Pb}\left(\mu \mathrm{g} \mathrm{kg}^{-1}\right)$ & $93.42^{\mathrm{a}} \pm 13.235$ & $69.78^{b} \pm 5.636$ & * & 1.67 & 1.40 & $0.5 \mathrm{mg} \mathrm{kg}^{-1} \mathrm{ww} \ddagger$ & \\
\hline
\end{tabular}

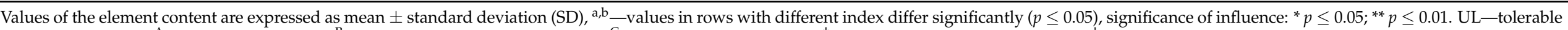

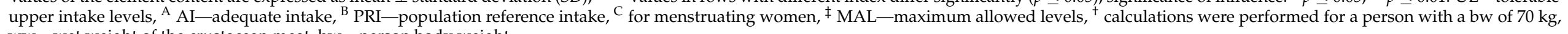
ww-wet weight of the crustacean meat, bw—person body weight. 
Table 4. Content of essential and nonessential amino acids in the abdomen and chelae muscles of F. limosus.

\begin{tabular}{|c|c|c|c|}
\hline $\begin{array}{l}\text { Amino Acids (mg g } \mathrm{g}^{-1} \text { of Meat) } \\
\text { (g } 100 \mathrm{~g}^{-1} \text { of Protein) }\end{array}$ & Abdomen & Chelae & $\begin{array}{c}\text { Influence } \\
\text { of Body Part }\end{array}$ \\
\hline Histidine & $\begin{array}{c}3.78 \pm 0.304 \\
(2.08 \pm 0.168)\end{array}$ & $\begin{array}{c}4.67 \pm 0.672 \\
(2.21 \pm 0.198)\end{array}$ & $\begin{array}{l}\text { n.s. } \\
\text { (n.s.) }\end{array}$ \\
\hline Arginine & $\begin{array}{c}19.42^{\mathrm{a}} \pm 2.037 \\
\left(10.67^{\mathrm{a}} \pm 1.154\right)\end{array}$ & $\begin{array}{l}14.93^{b} \pm 0.306 \\
\left(7.69^{b} \pm 0.141\right)\end{array}$ & * \\
\hline Isoleucine & $\begin{array}{c}7.42 \pm 0.580 \\
(4.07 \pm 0.265)\end{array}$ & $\begin{array}{c}8.30 \pm 1.104 \\
(3.89 \pm 0.079)\end{array}$ & $\begin{array}{l}\text { n.s. } \\
\text { (n.s.) }\end{array}$ \\
\hline Leucine & $\begin{array}{l}13.12 \pm 0.826 \\
(7.20 \pm 0.368)\end{array}$ & $\begin{array}{l}15.08 \pm 1.898 \\
(6.92 \pm 0.312)\end{array}$ & $\begin{array}{l}\text { n.s. } \\
\text { (n.s.) }\end{array}$ \\
\hline Lysine & $\begin{array}{l}14.10 \pm 1.120 \\
(7.74 \pm 0.628)\end{array}$ & $\begin{array}{l}15.22 \pm 2.010 \\
(7.28 \pm 0.490)\end{array}$ & $\begin{array}{l}\text { n.s. } \\
\text { (n.s.) }\end{array}$ \\
\hline Methionine & $\begin{array}{c}4.54 \pm 0.811 \\
(2.49 \pm 0.432)\end{array}$ & $\begin{array}{l}5.14 \pm 1.256 \\
(2.45 \pm 1.004)\end{array}$ & $\begin{array}{l}\text { n.s. } \\
\text { (n.s.) }\end{array}$ \\
\hline Tryptophan & $\begin{aligned} 5.71 & \pm 1.538 \\
(3.14 & \pm 0.847)\end{aligned}$ & $\begin{aligned} 6.04 & \pm 3.435 \\
(3.20 & \pm 1.441)\end{aligned}$ & $\begin{array}{l}\text { n.s. } \\
\text { (n.s.) }\end{array}$ \\
\hline Tyrosine & $\begin{array}{l}5.96 \pm 0.396 \\
(3.27 \pm 0.190)\end{array}$ & $\begin{array}{c}6.45 \pm 0.774 \\
(3.07 \pm 0.089)\end{array}$ & $\begin{array}{l}\text { n.s. } \\
\text { (n.s.) }\end{array}$ \\
\hline Phenylalanine & $\begin{aligned} 6.81 & \pm 0.452 \\
(3.74 & \pm 0.216)\end{aligned}$ & $\begin{array}{c}7.1 \pm 0.888 \\
(3.41 \pm 0.221)\end{array}$ & $\begin{array}{l}\text { n.s. } \\
\text { (n.s.) }\end{array}$ \\
\hline Valine & $\begin{aligned} 7.28 & \pm 0.585 \\
(3.99 & \pm 0.263)\end{aligned}$ & $\begin{array}{c}7.84 \pm 0.952 \\
(3.72 \pm 0.0 .132)\end{array}$ & $\begin{array}{l}\text { n.s. } \\
\text { (n.s.) }\end{array}$ \\
\hline Threonine & $\begin{aligned} 6.63 & \pm 0.422 \\
(3.64 & \pm 0.221)\end{aligned}$ & $\begin{array}{c}8.02 \pm 1.212 \\
(3.74 \pm 0.093)\end{array}$ & $\begin{array}{l}\text { n.s. } \\
\text { (n.s.) }\end{array}$ \\
\hline Total essential amino acids (EAA) & $\begin{array}{c}94.79 \pm 6.956 \\
(52.03 \pm 3.862)\end{array}$ & $\begin{array}{l}100.28 \pm 11.244 \\
(47.580 \pm 0.306)\end{array}$ & $\begin{array}{l}\text { n.s. } \\
\text { (n.s.) }\end{array}$ \\
\hline Alanine & $\begin{array}{c}9.38^{\mathrm{a}} \pm 0.689 \\
\left(5.14^{\mathrm{a}} \pm 0.354\right)\end{array}$ & $\begin{array}{l}10.85^{b} \pm 0.961 \\
\left(5.15^{b} \pm 0.071\right)\end{array}$ & $\begin{array}{c}* \\
* \\
(*)\end{array}$ \\
\hline Aspartic acid & $\begin{array}{l}17.70 \pm 1.189 \\
(9.71 \pm 0.577)\end{array}$ & $\begin{array}{l}17.85 \pm 1.966 \\
(8.55 \pm 0.381)\end{array}$ & $\begin{array}{l}\text { n.s. } \\
\text { (n.s.) }\end{array}$ \\
\hline Cysteine & $\begin{array}{c}2.08 \pm 0.749 \\
(1.14 \pm 0.409)\end{array}$ & $\begin{array}{c}2.47 \pm 1.244 \\
(0.99 \pm 0.436)\end{array}$ & $\begin{array}{l}\text { n.s. } \\
\text { (n.s.) }\end{array}$ \\
\hline Glutamic acid & $\begin{array}{c}29.55 \pm 2.139 \\
(16.21 \pm 0.980)\end{array}$ & $\begin{array}{c}32.92 \pm 4.322 \\
(15.49 \pm 0.110)\end{array}$ & $\begin{array}{l}\text { n.s. } \\
\text { (n.s.) }\end{array}$ \\
\hline Glycine & $\begin{array}{l}12.02^{\mathrm{a}} \pm 1.109 \\
\left(6.61^{\mathrm{a}} \pm 0.747\right)\end{array}$ & $\begin{array}{c}9.38^{b} \pm 1.290 \\
\left(4.58^{b} \pm 0.798\right)\end{array}$ & $\begin{array}{c}* \\
(*)\end{array}$ \\
\hline Proline & $\begin{array}{c}5.22^{\mathrm{a}} \pm 0.263 \\
\left(2.86^{\mathrm{a}} \pm 0.092\right)\end{array}$ & $\begin{array}{c}6.59^{b} \pm 1.045 \\
\left(2.94^{b} \pm 0.075\right)\end{array}$ & $\begin{array}{l}* \\
(*)\end{array}$ \\
\hline Serine & $\begin{array}{c}6.88 \pm 0.318 \\
(3.78 \pm 0.161)\end{array}$ & $\begin{array}{c}7.26 \pm 0.768 \\
(3.49 \pm 0.025)\end{array}$ & $\begin{array}{l}\text { n.s. } \\
\text { (n.s.) }\end{array}$ \\
\hline $\begin{array}{l}\text { Total nonessential amino acids } \\
\text { (NEAA) }\end{array}$ & $\begin{aligned} 82.83 & \pm 5.366 \\
(45.47 & \pm 2.844)\end{aligned}$ & $\begin{array}{l}87.32 \pm 10.469 \\
(41.19 \pm 0.433)\end{array}$ & $\begin{array}{l}\text { n.s. } \\
\text { (n.s.) }\end{array}$ \\
\hline EAA:NEAA & $1.14 \pm 0.0116$ & $1.15 \pm 0.0146$ & n.s. \\
\hline
\end{tabular}

Values are expressed as mean \pm standard deviation (SD), ${ }^{\text {ab }}$ - values in rows with different index differ significantly ( $p \leq 0.05$ ), significance of influence: n.s. - non-significant, ${ }^{*} p \leq 0.05$.

The identified differences are likely to be directly associated with the function of these muscle groups, and in particular, with the activity of their metabolic pathways. For example, the higher level of arginine in abdomen muscles compared with that in chelae 
is associated with the functioning of the highly efficient arginine phosphate/arginine kinase system, which is crucial for burst locomotion, swimming, and egg incubation in females [64]. The higher level of alanine in chelae muscles in postmolt animals may be related to some aspects of electrolyte balance during the dilution of electrolytes associated with ecdysis [65]. Arg, Leu, and Lys were the most frequent amino acids in the EAA group, and Glu and Asp were the most frequent amino acids in the NEAA group. Comparison of amino acid profiles between the meat of F. limosus and livestock [41,66-68] and fish [69-71] showed that raw material collected from spiny-cheek crayfish has similar or higher free amino acid concentrations (Arg, Ile, Leu, Trp, Glu) than that from vertebrates. According to Claybrook [72], this is a manifestation of differing osmoregulatory needs. The essential amino acids to nonessential amino acids ratio (EAA:NEAA) in crayfish meat is at 1.14-1.15 and is higher than in the meat of chicken (0.94-1.02) [73] and duck (0.63) [66], but it is similar or slightly lower than in the meat of cattle (1.02-1.31) [41,68], pork (1.38), lamb (1.30) [41], and nutria (1.15-1.3) [74]. The high protein quality of abdomen and chelae meat was confirmed by chemical scores (CS) that, except for valine in chelae meat, were higher than 100 (Table 5).

Table 5. Nutritional quality of protein in the abdomen and chelae muscles of F. limosus.

\begin{tabular}{|c|c|c|c|c|}
\hline \multirow{2}{*}{ Amino Acids } & \multirow{2}{*}{$\begin{array}{l}\text { FAO/WHO/UNU [25] } \\
\text { Scoring Pattern } \\
\text { (g } 100 \mathrm{~g} \mathrm{~g}^{-1} \text { of Protein) }\end{array}$} & \multicolumn{3}{|c|}{$\begin{array}{c}\text { CS } \\
(\% \text { of Scoring Pattern) }\end{array}$} \\
\hline & & Abdomen & Chelae & $\begin{array}{l}\text { Influence } \\
\text { of Body Part }\end{array}$ \\
\hline Histidine & 1.5 & $138.53 \pm 11.167$ & $147.41 \pm 13.208$ & n.s. \\
\hline Isoleucine & 3.0 & $135.77 \pm 8.828$ & $129.63 \pm 2.639$ & n.s. \\
\hline Leucine & 5.9 & $122.06 \pm 6.243$ & $117.22 \pm 5.284$ & n.s. \\
\hline Lysine & 4.5 & $172.04 \pm 13.961$ & $161.86 \pm 10.890$ & n.s. \\
\hline SAA & 2.2 & $165.15 \pm 38.037$ & $156.43 \pm 83.732$ & n.s. \\
\hline Phe + Tyr & 3.8 & $184.34 \pm 10.639$ & $170.58 \pm 8.144$ & n.s. \\
\hline Threonine & 2.3 & $158.23 \pm 9.599$ & $162.56 \pm 4.043$ & n.s. \\
\hline Tryptophan & 0.6 & $522.77 \pm 141.237$ & $534.17 \pm 106.759$ & n.s. \\
\hline Valine & 3.9 & $102.42 \pm 6.737$ & $95.30 \pm 3.383$ & n.s. \\
\hline EAAI & & $151.53 \pm 12.434$ & $145.94 \pm 9.737$ & n.s. \\
\hline
\end{tabular}

Values are expressed as mean \pm standard deviation (SD), significance of influence: n.s.-non-significant; SAA—sulfur amino acids, EAAI—essential amino acids index.

Our study showed that the meat of spiny-cheek crayfish had a better nutritional protein quality in comparison with the FAO/WHO/UNU standards [25]. By analysing and recalculating the results obtained by other authors, it can be noted that the meat of cattle, pig, sheep [75], and rabbit [76] has higher CS values for His, Ile, Lou, Thr, and Val, similar CS values for Lys and Phe+Tyr, and lower CS values for Tyr compared with the meat of spiny-cheek crayfish. Moreover, the essential amino acid index (EAAI) calculated for the abdomen and chelae meat of F. limosus was $151.53 \%$ and $145.94 \%$, respectively, and it was higher than that for the reference standard protein (Table 4). The EAAI values in this study are higher comparing with the meat of several species, e.g., 114\% in lagoon crab Calinectes latimanus [77], 89\% in innards N. maculatus [78], 50.4-82.9\% in chicken [75,79], 80-81\% in beef, pork, and mutton [75], and 128-136\% in freshwater fish [80], similar as in rabbit meat-153\% [76], and lower than that in sea bass (Dicentrarchus labrax) fillets-266\% [81]. The level of protein, but also the CS and EAAI in the abdomen and chelae, showed that F. limosus meat is highly digestible and has a well-balanced amino acid composition.

The high nutritional value of crayfish meat protein can contribute to the wider use of this raw material for food purposes. However, it seems that abdomen meat is of greater importance than that from chelae. Due to its very low yield, chelae meat is not an eco- 
nomically viable raw material. However, it may be used in the production of, e.g., protein preparations, which are subsequently used in food processing [15,38]. We conducted a detailed analysis of the quality of the abdomen meat of spiny-cheek crayfish, which included assessment of the fatty acid (FA) profile, $\mathrm{pH}$, colour, structure, texture, and sensory properties.

The FA profile analysis (Table 6) showed that approximately $44.4 \%$ of FA in abdomen meat are polyunsaturated fatty acids (PUFA), while saturated (SFA) and monounsaturated (MUFA) fatty acids constitute $28.8 \%$ and $26.8 \%$, respectively. Therefore, it can be proposed that the proportion of PUFA, MUFA, and SFA in crayfish meat is more favourable than in pork [82,83], beef [84-86], lamb [87], chicken [53,87], and goose [88], all of which contain more SFA and MUFA than PUFA.

The higher value of the crayfish-derived raw material was confirmed by the PUFA:SFA ratio (1.45) which, according to nutritional recommendations, should be greater than 0.45 [89]. In comparison, the PUFA:SFA ratio was approximately 0.3 in pork [82,83], $0.25-0.79$ in beef [85,86], 0.19-0.2 in lamb [90], and 0.6 in chicken [87]. In crayfish meat, palmitic acid (C16:0) was the most abundant SFA, the sum of oleic (C18:1n9c) and elaidic (C18:1n9t) acids was the most abundant MUFA, and eicosapentaenoic acid (EPA, C20:5n3) was the most abundant PUFA. In the PUFA subset, the quantities of n-3, n- 6 , and n9 acids were similar $\left(0.0850-0.0895 \mathrm{~g} 100 \mathrm{~g}^{-1}\right.$ of meat), and the $\mathrm{n}-3 / \mathrm{n}-6$ ratio was 1.08 $(n-6 / n-3=0.93)$. The $n-3 / n-6$ ratio was comparable with the results reported by other authors (0.72-1.06) for various crayfish species $[19,20,90]$. The obtained n-3/n-6 (or n$6 / n-3)$ ratio for crayfish meat meets nutritional recommendations $(>0.25$ or $<4.0)$ [89], and it is more beneficial than that calculated for the meat of several livestock species, e.g., $0.10-0.21$ in pork [82,83], 0.08-0.18 in beef [85,86], 0.07 in rabbit [91], 0.07-0.12 in chicken [53,87], and 0.13-0.18 in goose [88]. Only for the meat of marine fish (e.g., Pacific herring, Clupea harengus pallasi; Pacific hake, Merluccius productus; sardine, Sardinops sagax; walleye pollock, Theragra chalcogramma), this ratio was much higher than that for crayfish meat and ranged between 7.35 and 18.66 [92]. In our study, $100 \mathrm{~g}$ of crayfish meat contained $0.0688 \mathrm{~g}$ of the sum of EPA and DHA (docosahexaenoic acid), which is much more than pork-0.0118 [83] and chicken-0.037 [87].

Additionally, h/H, AI, and TI calculated based on the FA profile of abdomen meat were 3.30, 0.29, and 0.29, respectively (Table 6), indicating a high nutritional value of crayfish meat fat. The $\mathrm{h} / \mathrm{H}$ index indicates the influence of specific fatty acids on cholesterol metabolism, and generally the higher the value, the better. The value of the $h / H$ index obtained in our study was higher than that reported for the meat of several livestock species, e.g., 1.8-2.66 in chicken [53,93], 2.6-2.8 in goose [88], 1.8 in beef [94], and 2.4 in pork [95]. Further comparisons of the $\mathrm{h} / \mathrm{H}$ indices showed that the value calculated for F. limosus meat fell within the range for fillets of marine fish-3.1 [96] and freshwater common carp-3.4 [97], and it was lower compared with 5.9 in crab edible tissue [98]. In terms of human health, the AI and TI take into account the different effects that a single FA might have on human health, and lower values of these indices ( $<1.0$ for AI, $<0.5$ for TI) in the diet are strongly recommended [96]. Our study showed that the abdomen meat of spiny-cheek crayfish meets these requirements and can be recommended for delaying atherosclerosis and thus for minimising the risk of cardiovascular disorders [28,29]. The AI and TI values obtained for crayfish meat were lower than for the meat of several other species, e.g., AI 0.6-0.84 in beef [84], AI 0.56-0.6; TI 1.35-1.50 in lamb [90], AI 0.38-0.39; TI $0.75-0.80$ in chicken [53] and AI 0.36-0.37; TI 0.66-0.74 in goose [88]. 
Table 6. Content of fatty acids in the abdomen meat of F. limosus.

\begin{tabular}{|c|c|c|}
\hline Fatty Acid (g $100 \mathrm{~g}^{-1}$ of Meat) & Mean Value & SD \\
\hline (C12:0) Lauric acid & 0.0006 & 0.00050 \\
\hline (C14:0) Myristic acid & 0.0026 & 0.00099 \\
\hline (C15:0) Pentadecanoic acid & 0.0029 & 0.00099 \\
\hline (C16:0) Palmitic acid & 0.0654 & 0.02500 \\
\hline (C17:0) Heptadecanoic acid & 0.0042 & 0.00106 \\
\hline (C18:0) Stearic acid & 0.0309 & 0.00891 \\
\hline (C20:0) Arachidic acid & 0.0016 & 0.00113 \\
\hline (C21:0) Heneicosanoic acid & 0.0004 & 0.00042 \\
\hline (C22:0) Behenic acid & 0.0022 & 0.00177 \\
\hline Total SFA & 0.1111 & 0.04144 \\
\hline (C16:1n7) Palmitoleic acid & 0.0141 & 0.00856 \\
\hline (C17:1n7) cis-10-Heptadecenoic acid & 0.0036 & 0.00148 \\
\hline$(\mathrm{C} 18: 1 \mathrm{n} 9 \mathrm{t}+\mathrm{C} 18: 1 \mathrm{n} 9 \mathrm{c})$ Elaidic acid + Oleic acid & 0.0812 & 0.03147 \\
\hline (C20:1n5) cis-11-Eicosenoic acid & 0.0010 & 0.00035 \\
\hline (C20:1n9) cis-9-Eicosenoic acid & 0.0038 & 0.00156 \\
\hline Total MUFA & 0.1036 & 0.04363 \\
\hline (C18:2n6t) Linolelaidic acid & 0.0012 & 0.00057 \\
\hline (C18:2n6c) Linoleic acid & 0.0238 & 0.01068 \\
\hline (C18:3n3) alfa-Linolenic acid [ALA] & 0.0087 & 0.00354 \\
\hline (C20:2n6) cis-11.14-Eicosadienoic acid & 0.0102 & 0.00474 \\
\hline (C20:3n6) cis-8.11.14-Eicosatrienoic acid [DGLA] & 0.0010 & 0.00057 \\
\hline (C20:4n6) Arachidonic acid [AA] & 0.0436 & 0.02319 \\
\hline (C20:3n3) cis-11.14.17-Eicosatrienoic acid [ETE] & 0.0025 & 0.00141 \\
\hline (C20:5n3) cis-5.8.11.14.17-Eicosappentaenoic acid [EPA] & 0.0670 & 0.04179 \\
\hline (C22:6n3) cis-4.7.10.13.16.19-Docosahexaenoic acid [DHA] & 0.0018 & 0.00120 \\
\hline Total PUFA & 0.1712 & 0.09362 \\
\hline Total n-3 PUFA & 0.0895 & 0.0528 \\
\hline $\mathrm{EPA}+\mathrm{DHA}$ & 0.0688 & 0.04299 \\
\hline Total n-6 PUFA & 0.0890 & 0.03974 \\
\hline Total n-9 PUFA & 0.0850 & 0.03302 \\
\hline PUFA: SFA & 1.45 & 0.2880 \\
\hline$n-3 / n-6$ & 1.08 & 0.1235 \\
\hline h:H & 3.30 & 0.4154 \\
\hline $\mathrm{AI}$ & 0.29 & 0.0360 \\
\hline TI & 0.29 & 0.0654 \\
\hline
\end{tabular}

Values are expressed as mean \pm standard deviation (SD).

\subsection{Culinary Properties of Spiny-Cheek Crayfish Meat}

When analysing culinary quality parameters, it can be noted that the abdomen meat has a fine texture and a pleasant smell. Hence, this raw material can be attractive to older people who have a problem with chewing food. The meat is soft, cohesive, springy and juicy, easily chewed, without clearly perceptible connective tissue and fattiness (Table 7). 
Table 7. Sensory properties of the F. limosus abdomen meat.

\begin{tabular}{|c|c|c|}
\hline Parameters (pt.) & Mean Values & Standard Deviation (SD) \\
\hline \multicolumn{3}{|l|}{ Texture: } \\
\hline Springiness & 3.19 & 0.2394 \\
\hline Cohesiveness & 3.23 & 0.4270 \\
\hline Hardness & 2.62 & 0.6614 \\
\hline Tenderness & 1.73 & 0.2668 \\
\hline Moisture & 1.58 & 0.3536 \\
\hline Juiciness & 2.04 & 0.2205 \\
\hline Perceptibility of connective tissue & 1.29 & 0.2500 \\
\hline Chewiness & 1.96 & 0.2205 \\
\hline Fattiness & 1.02 & 0.0417 \\
\hline Astringency & 1.54 & 0.4167 \\
\hline \multicolumn{3}{|l|}{ Odour: } \\
\hline Boiled meat & 1.79 & 0.5713 \\
\hline Fishy & 1.79 & 0.5833 \\
\hline Seaweed & 1.54 & 0.7120 \\
\hline \multicolumn{3}{|l|}{ Taste: } \\
\hline Boiled meat & 1.29 & 0.2764 \\
\hline Fish & 1.38 & 0.5951 \\
\hline Seaweed & 1.38 & 0.5951 \\
\hline Sweet & 1.56 & 0.5543 \\
\hline Bitter & 1.64 & 0.6138 \\
\hline
\end{tabular}

Values are expressed as mean \pm standard deviation (SD).

Compared with the meat of other animals, that of spiny-cheek crayfish has a lower hardness than that of cattle and goat, lower fattiness than that of cattle, goat, sheep, pig, roe-deer and reindeer, and higher juiciness than that of goat and sheep [99]. Due to the high cohesiveness, crayfish meat is not as tender as that of most species of livestock and game. The results of the sensory assessment of crayfish meat texture were confirmed by instrumental analysis (Table 8). However, it is difficult to compare these results with texture analyses of other meat species because of the large variation of parameters used in tests (type of force, extent of deformation, size of shaft, test speed). For example, with the compression plate used in our study, the hardness of crayfish meat measured was $31 \mathrm{~N}$. In studies by other authors, in which penetration shafts were used, hardness was $4.8 \mathrm{~N}$ in common carp [100], 25.2 N in common pheasant (Phasianus colchicus) [101], 27.7 N in roe deer (Capreolus preolus), and $47 \mathrm{~N}$ in wild boar (Sus scrofa) [102]. A much greater hardness was shown for pig (56 to $100 \mathrm{~N})[103,104]$ and cattle meat (30.5 to $68.7 \mathrm{~N}$ ) [105]. In turn, Hamre et al. [106], using a compression test at lower deformation values than in our study $(60 \%$ vs. $80 \%)$, reported the hardness of Atlantic salmon fillets at $5.8 \mathrm{~N}$.

Textural properties are also inherently related to the $\mathrm{pH}$ of meat. The meat of the spiny-cheek crayfish abdomen had a $\mathrm{pH}$ of 7.17 , which is similar to the $\mathrm{pH}$ of $P$. clarkii abdomen meat (6.98) [16]. However, the observed $\mathrm{pH}$ of crayfish meat is much higher than the final $\mathrm{pH}$ of livestock meat (5.1-6.2), which causes a lower microbiological stability of crayfish meat despite the decrease in meat $\mathrm{pH}$ during storage [107]. A positive feature of spiny-cheek crayfish meat is its light colour and odour profile. In terms of colour, crayfish meat resembles more fish and chicken meat than that of livestock mammals. The high lightness $\left(\mathrm{L}^{*}\right)$ and low redness $\left(\mathrm{a}^{*}\right)$ obtained for crayfish meat were comparable with carp [100] and poultry meat [108]. The yellowness $\left(b^{*}\right)$ of crayfish meat was low and similar 
to that of pork $[109,110]$ but much lower than that of beef $[111,112]$, poultry [108], wild boar [113], and carp [100]. The chromaticity of crayfish meat (C) was lower than that of livestock [108,109,111,112] and carp [100] meat.

Table 8. Texture parameters and physicochemical properties of the F. limosus abdomen meat.

\begin{tabular}{ccc}
\hline Parameters & Mean Values & Standard Deviation (SD) \\
\hline Hardness $(\mathrm{N})$ & 31.03 & 8.795 \\
\hline Cohesiveness $(-)$ & 0.216 & 0.0340 \\
\hline Springiness $(\mathrm{cm})$ & 0.19 & 0.039 \\
\hline Chewiness $(\mathrm{N} \times \mathrm{cm})$ & 1.20 & 0.228 \\
\hline $\mathrm{pH}$ & 7.17 & 0.180 \\
\hline $\mathrm{L}^{*}$ & 46.77 & 2.353 \\
\hline $\mathrm{a}^{*}$ & 3.07 & 0.419 \\
\hline $\mathrm{b}^{*}$ & 6.56 & 1.847 \\
\hline $\mathrm{WI}$ & 46.26 & 2.523 \\
\hline $\mathrm{C}$ & 7.30 & 1.578
\end{tabular}

Values are expressed as mean \pm standard deviation (SD). $\mathrm{L}^{*}$ (lightness), $\mathrm{a}^{*}$ (redness), $\mathrm{b}^{*}$ (yellowness), WI (whiteness index), C (chromaticity).

The fine texture of crayfish meat is due to the small size of muscle fibres and thin connective tissue surrounding the fibres (Table 9). The size of muscle fibres in F. limosus muscles, characterised by the CSA, girth, V and $\mathrm{H}$ diameters, is smaller compared with that of other aquatic and terrestrial animals. For example, the CSA of muscle fibres in F. limosus $\left(85.04 \mu^{2}\right)$ is four times smaller than that in horseshoe crab, Limulus polyphemus$484 \mu \mathrm{m}^{2}$ [114]. Even greater differences in fibre size were observed when comparing crayfish meat to that of various fish species-sea bass [115], common carp [100], tench [116], as well as livestock-pork [103,104], beef [117], chicken [118], and duck [119].

Table 9. The structural elements of the F. limosus abdomen meat.

\begin{tabular}{cccc}
\hline \multirow{2}{*}{ Parameters } & \multicolumn{2}{c}{ Body Part } & \multirow{2}{*}{$\begin{array}{c}\text { Significance } \\
\text { of Influence }\end{array}$} \\
\cline { 2 - 4 } & Abdomen & Chelae & $* *$ \\
\hline Fibre cross-section area $\left(\mu \mathrm{m}^{2}\right)$ & $85.04^{\mathrm{a}} \pm 12.222$ & $38.52^{\mathrm{b}} \pm 7.946$ & $* *$ \\
\hline Fibre girth $(\mu \mathrm{m})$ & $51.09^{\mathrm{a}} \pm 4.829$ & $32.50^{\mathrm{b}} \pm 2.730$ & $*$ \\
\hline Horizontal fibre diameter $(\mathrm{H}),(\mu \mathrm{m})$ & $10.89^{\mathrm{a}} \pm 1.348$ & $6.74^{\mathrm{b}} \pm 0.648$ & $*$ \\
\hline Vertical fibre diameter $(\mathrm{V}),(\mu \mathrm{m})$ & $14.32^{\mathrm{a}} \pm 1.659$ & $9.20^{\mathrm{b}} \pm 0.865$ & \multirow{2}{*}{} \\
\hline Fibre shape $(\mathrm{H}: \mathrm{V})$ & $0.768 \pm 0.0117$ & $0.748 \pm 0.0305$ & n.s. \\
\hline Endomysium thickness $(\mu \mathrm{m})$ & $1.20 \pm 0.1609$ & $1.05 \pm 0.0332$ & n.s. \\
\hline
\end{tabular}

Values are expressed as mean \pm standard deviation (SD), ${ }^{\text {b }}$ - values in rows with different index differ significantly $(p \leq 0.05)$, significance of influence: n.s. -non-significant, $* * * 0.01$.

Some of the most important sensory properties of the meat of aquatic animals are the intensive odour and flavour (fishy, seaweed), which depend particularly on storage conditions [120]. In the case of crayfish meat, the detectability of odour and taste that is typical of the animal species is lower than that of beef, goat, reindeer, and roe deer [99]. No sour and metallic flavours, which are detectable in the meat of livestock and game animals, were observed in crayfish meat. The bitter flavour found in crayfish meat was much less intense than that found in the meat of cattle, reindeer, roe deer, goat, rabbit, and even chicken [99]. Spiny-cheek crayfish meat was characterised by a low intensity of odour and taste indices, which are preferable by consumers. For the above reasons, 
crayfish meat can be an attractive source of protein, fatty acids, and minerals in children's diet. This group of consumers is particularly demanding as they are reluctant to eat fish meat, a rich source of nutrients (e.g., amino acids, EPA, DHA, etc.) for their developing bodies because of its specific odour and the presence of fish bones.

\section{Conclusions}

The meat of spiny-cheek crayfish is regarded by the food industry as an alternative source of raw material. Our study provides detailed and multidisciplinary results showing the following. (i) Despite the low unit yield of meat extracted from chelae and abdomen, both types of raw material have a high level of protein and a low content of fat. (ii) Chemical scores (CS) and the essential amino acid index (EAAI) calculated for the abdomen and chelae meat of $F$. limosus have a better nutritional protein quality in comparison with the FAO/WHO/UNU (2007) standards. (iii) The quality of crude fat expressed, e.g., by the ratio of n-3 to $n-6$ fatty acids and three indexes $(h / H, I A, I T)$, is unquestionably beneficial for human health. (iv) Abdomen and chelae meat are both highly nutritious and toxicologically safe concerning heavy metals. (v) The culinary properties of spiny-cheek crayfish meat assessed using numerous parameters of structure, texture, colour and sensory parameters are high for both technologists and consumers. Our study covered a significant gap in the knowledge required by the food industry to begin the exploitation and efficient processing of spiny-cheek crayfish meat. However, ongoing exploitation possibly will eventually lead to the successful eradication of the invasive species, and the food industry must close or may import the material from other countries where F. limosus is present as well as change its target species. The results of our research can also be used by chefs. On their basis, it is possible to prepare new, sensory-attractive and nutritious dishes made of spiny-cheek crayfish meat as well as diversify and improve the nutritional value of the already offered dishes made of traditional raw materials.

Supplementary Materials: The following are available online at https:/ /www.mdpi.com/2076-261 5/11/1/59/s1. Table S1: The accuracy of the analytical method verified against certified reference material: ERM-BB422 Fish muscle.

Author Contributions: Conceptualisation, N.Ś., R.P. and M.S.; methodology, N.Ś., R.P. and M.S.; formal analysis, R.P. and M.S.; investigation, N.Ś., R.P., M.S., P.Ś. and A.N.; resources, R.P., M.S. and P.Ś.; data curation, R.P. and M.S.; writing—original draft preparation, N.Ś., R.P., M.S., P.Ś. and A.N.; writing—review and editing, N.Ś., R.P., M.S., P.Ś. and A.N.; visualisation, N.Ś., R.P. and M.S.; supervision, R.P. and M.S.; project administration, R.P.; funding acquisition, R.P., M.S., and P.Ś All authors have read and agreed to the published version of the manuscript.

Funding: This study was funded by the Department of Meat Sciences of the West Pomeranian University of Technology, Szczecin and by the Institute of Marine and Environmental Sciences of the University of Szczecin.

Institutional Review Board Statement: The study was accepted by the Faculty Board under the number 517-08-026-7724/17 and no restrictions were raised by the Ethics Committee.

Informed Consent Statement: Not applicable.

Data Availability Statement: The data presented in this study are available on request from the corresponding author. The data are not publicly available due to privacy.

Acknowledgments: We would like to thank Marek Budniak and Bogdan Kisiel for field assistance (sampling by scuba diving).

Conflicts of Interest: The authors declare no conflict of interest.

\section{References}

1. Patoka, J.; Kocánová, B.; Kalous, L. Crayfish in Czech cultural space: The longest documented relationship between humans and crayfish in Europe. Knowl. Manag. Aquat. Ecosyst. 2016, 417, 5. [CrossRef]

2. Śmietana, P. Uwarunkowania Rozmieszczenia i Mechanizmy Konkurencji Międzygatunkowej Raka Szlachetnego (Astacus astacus L.) i raka Pręgowatego (Orconectes limosus Raf.); Habilitation Thesis; Uniwersytet Szczeciński: Szczecin, Poland, 2013. (In Polish) 
3. Kouba, A.; Petrusek, A.; Kozák, P. Continental-wide distribution of crayfish species in Europe: Update and maps. Knowl. Manag. Aquat. Ecosyst. 2014, 413. [CrossRef]

4. Kaldre, K.; Paaver, T.; Hurt, M.; Gross, R. Continuing expansion of non-indigenous crayfish species in Northern Europe: First established spiny-cheek crayfish Faxonius limosus (Refinesque, 1817) population in Estonia. BioInvasions Rec. 2020, 9 , 127-132. [CrossRef]

5. Souty-Grosset, C.; Holdich, D.M.; Noël, P.Y.; Reynolds, J.D.; Haffner, P. Atlas of Crayfish in Europe; Muséum National d'Histoire Naturelle: Paris, France, 2006.

6. Non-Native Species Secretariat. Rick Assessment for Orconectes Limosus-Spiny-Cheek Crayfish. Risk Assessment Carried Out for Great Britain. 2011. Available online: http:/ / www.nonnativespecies.org/index.cfm?pageid=143 (accessed on 8 August 2020).

7. Haertel-Borer, S.S.; Zak, D.; Eckmann, R.; Baade, U.; Hölker, F. Population density of the crayfish, Orconectes limosus, in relation to fish and macroinvertebrate densities in a small mesotrophic lake-Implications for the lake's food web. Int. Rev. Hydrobiol. 2005, 90, 523-533. [CrossRef]

8. Pilotto, F.; Free, G.; Crosa, G.; Sena, F.; Ghiani, M.; Cardoso, A.C. The invasive crayfish Orconectes limosus in Lake Varese: Estimating abundance and population size structure in the context of habitat and methodological constraints. J. Crust. Biol. 2008, 28, 633-640. [CrossRef]

9. Baek, H.H.; Cadwallader, K.R. Volatile compounds in flavor concentrates produced from crayfish-processing by products with and without protease treatment. J. Agric. Food Chem. 1996, 44, 3262-3267. [CrossRef]

10. Felix, M.; Romero, A.; Rustad, T.; Guerrero, A. Physicochemical, microstructure and bioactive characterization of gels mad from crayfish protein. Food Hydrocoll. 2017, 63, 429-436. [CrossRef]

11. Meyers, S.P.; Chen, H.M.; No, H.K.; Lee, K.S. An integrated approach to recovery and utilization of Louisiana crawfish processing wastes. In Making Profits Out of Seafood Wastes; Keller, S., Ed.; University of Alaska Sea Grant: Anchorage, AK, USA, 1990; pp. 161-171.

12. Struszczyk, M.H. Chitin and chitosan, Part II applications of chitosan. Polimery 2002, 47, 396-403. [CrossRef]

13. Ulikowski, D.; Cybowski, Ł.; Traczuk, P.; Ulikowska, E. A new design of crayfish traps reduces escaping and improves opportunities for long-term catching. Turk. J. Fish. Aquat. Sci. 2017, 17, 363-369. [CrossRef]

14. Abd-Elgawad, A.I.; Qassem, A.E.; Ghoneim, G.A.; El Bhery, S.M. Preparation untraditional burger by using crayfish (Procambarus clarkii). J. Dairy Sci. 2018, 9, 245-250. [CrossRef]

15. Abou-Zaid, A.A.M.; Elbandy, M.A.S. Production and quality evaluation of nutritious high-quality biscuits and potato puree tablets supplemented with crayfish Procomburus clarkia protein products. Res. J. Appl. Sci. 2014, 10, 43-53.

16. El-Sherif, S.A.H.; El-Ghafour, S.A. Nutritive value of canned River Nile Crayfish (Procambarus clarkii) products. Egypt. J. Aquat. Res. 2015, 41, 265-272. [CrossRef]

17. Harlioğlu, A.G.; Aydin, S.; Yilmaz, Ö. Fatty acid, cholesterol and fat-soluble vitamin composition of wild and captive freshwater crayfish (Astacus leptodactylus). Food Sci. Technol. Int. 2012, 18, 93-100. [CrossRef]

18. Thompson, K.R.; Muzinic, L.A.; Yancey, D.H.; Webster, C.D.; Rouse, D.B.; Xiong, Y. Growth, processing measurements, tail meat yield, and tail meat proximate composition of male and female Australian red claw crayfish, Cherax quardicarinatus, stocked into earthen pounds. J. Appl. Aquac. 2004, 16, 117-129. [CrossRef]

19. Stanek, M.; Kupcewicz, B.; Dąbrowski, J.; Janicki, B. Ocena zawartości tłuszczu i profilu kwasów tłuszczowych w mięsie raka pręgowatego (Orconestes limosus Raf.) z rzeki Brdy i jeziora Gopło. J. Cent. Eur. Agric. 2010, 11, 297-304. (In Polish)

20. Stanek, M.; Borejszo, Z.; Dabrowski, J.; Janicki, B. Fat and cholesterol content and fatty acid profiles in edible tissues of spiny-cheek crayfish, Orconestes limosus (Raf.) from Lake Gopło (Poland). Arch. Polish Fish. 2011, 19, 241-248. [CrossRef]

21. Stanek, M.; Borejszo, Z.; Dąbrowski, J.; Janicki, B. Impact of sex and size range on fat, cholesterol content, and fatty acid profiles in edible tissues of spiny-cheek crayfish (Orconectes limosus Raf.) from Lake Gopło (Poland). Arch. Polish Fish. 2013, 21, 259-270. [CrossRef]

22. Buchanan, K.; Burt de Perera, T.; Carere, C.; Carter, T.; Hailey, A.; Hubrecht, R.; Jennings, D.; Metcalfe, N.; Pitcher, T.; Peron, F.; et al. Guidelines for the treatment of animals in behavioural research and teaching. Anim. Behav. 2012, 83, 301-309. [CrossRef]

23. Latimer, G.W. Official Methods of Analysis of AOAC International, 21st ed.; Association of Official Analytical Chemists: Gaithersburg, MD, USA, 2019.

24. Regulation (EU) No 1169/2011 of the European Parliament and of the Council of 25 October 2011 on the provision of food information to consumers, amending Regulations (EC) No 1924/2006 and (EC) No 1925/2006 of the European Parliament and of the Council, and repealing Commission Directive 87/250/EEC, Council Directive 90/496/EEC, Commission Directive 1999/10/EC, Directive 2000/13/EC of the European Parliament and of the Council, Commission Directives 2002/67/EC and 2008/5/EC and Commission Regulation (EC) No 608/2004. OJ L 304/18, 22 November 2011.

25. FAO/WHO/UNU. Protein and Amino Acid Requirements in Human Nutrition; WHO Technical Report Series; WHO: Geneva, Switzerland, 2007. Available online: https://www.who.int/nutrition/publications/nutrientrequirements/WHO_TRS_935/en/ (accessed on 8 August 2020).

26. Shahidi, F.; Synowiecki, J. Nutrient composition of mechanically separated and surimi like seal meat. Food Chem. 1993, 47, 41-46. [CrossRef]

27. Fernández, M.; Ordoñez, J.A.; Cambero, I.; Santos, C.; Pin, C.; De la Hoz, L. Fatty acid composition of selected varieties of Spanish dry ham related to their nutritional implications. Food Chem. 2007, 101, 107-112. [CrossRef] 
28. Fehily, A.M.; Pickering, J.E.; Yarnell, J.W.G.; Elwood, P.C. Dietary indexes of atherogenicity and thrombogenicity and ischaemic heart disease risk: The Caerphilly prospective study. Br. J. Nutr. 1994, 71, 249-257. [CrossRef]

29. Ulbricht, T.L.V.; Southgate, D.A.T. Coronary heart disease: Seven dietary factors. Lancet 1991, 338, 985-992. [CrossRef]

30. Mistri, M.; Munari, C.; Pagnoni, A.; Chenet, T.; Pasti, L.; Cavazzini, A. Accumulation of trace metals in crayfish tissues: Is Procambarus clarkii a vector of pollutants in Po Delta inland waters? Eur. Zool. J. 2020, 87, 46-57. [CrossRef]

31. Jastrzębska, A. Modifications of spectrophotometric methods for total phosphorus determination in meat samples. Chem. Pap. 2009, 63, 47-54. [CrossRef]

32. Burck, H.C. Technika Histologiczna; PZWL: Warszawa, Poland, 1975; pp. 139-140. (In Polish)

33. Bourne, M. Food Texture and Viscosity: Concept and Measurement; Academic Press: San Diego, CA, USA, 1982.

34. PN-ISO 11036:1999 Standard. Available online: http://sklep.pkn.pl/pn-iso-11036-1999p.html (accessed on 17 September 2020).

35. Berber, S.; Balik, S. Apolyont gölü (Bursa-Türkiye) Tatlisu İstakozunun (Astacus leptodactylus Eschscholtz, 1823) boy-ağırlık ilişkisi ve et verimi. J. Fish. Sci. 2009, 3, 86-99. (In Polish) [CrossRef]

36. Harlioğlu, M.M.; Holdich, D.M. Meat yields in the introduced freshwater crayfish, Pacifastacus leniusculus (Dana) and Astacus leptodactylus Eschscholtz, from British waters. Aquac. Res. 2001, 32, 411-417. [CrossRef]

37. Stein, R.A. Sexual dimorphism in crayfish chelae: Functional significance linked to reproductive activities. Can. J. Zoöl. 1976, 54, 220-227. [CrossRef]

38. Curulli, F.; Gorczyca, E.M.; Leonard, B.V. Extraction and characterisation of meat from the claws of freshwater crayfish using dense media. J. Sci. Food Agric. 2000, 80, 201-208. [CrossRef]

39. Kovačević, T.B.; Borković-Mitić, S.S.; Pavlović, S.Z.; Radojičić, R.M.; Saičić, Z.S. The concentrations of antioxidant compounds in the hepatopancreas, the gills and muscle of some freshwater crayfish species. Acta Biol. Hung. 2006, 57, 449-458. [CrossRef]

40. Hantoush, A.A. Nutritional value of important commercial fish from Iraqi waters. Int. J. Mar. Sci. 2015, 5, 1-5. [CrossRef]

41. Ahmad, R.S.; Imran, A.; Hussain, M.B. Nutritional Composition of Meat. In Meat Science and Nutrition; IntechOpen: London, UK, 2018; pp. 61-77.

42. Wyness, L.; Weichselbaum, E.; O'Connor, A.; Williams, E.B.; Benelam, B.; Riley, H.; Stanner, S. Red meat in the diet: An update. Nutr. Bull. 2011, 36, 34-77. [CrossRef]

43. Sikorski, Z.E. Ryby i Bezkręowce Morskie. In Pozyskiwanie, Właściwości i Przetwarzanie; WNT: Warszawa, Poland, 2004. (In Polish)

44. Ackman, R. Seafood lipids and fatty acids. Food Rev. Int. 1990, 6, 617-646. [CrossRef]

45. El-Kholie, E.M. Chemical, physical, microbiological and quality attributes studies on River Nile crayfish. Afr. J. Biotechnol. 2012, 11, 11262-11270. [CrossRef]

46. Pereira, P.C.; Vicente, A.F.D.R.B. Meat nutritional composition and nutritive role in the human diet. Meat Sci. 2013, 93, 586-592. [CrossRef]

47. Strazdina, V.; Jemeljanovs, A.; Šterna, V. Nutrition Value of Wild Animal Meat. Proc. Latv. Acad. Sci. Sect. B Nat. Exact. Appl. Sci. 2013, 67, 373-377. [CrossRef]

48. Williams, P. Nutritional composition of red meat. Nutr. Diet. 2007, 64, S113-S119. [CrossRef]

49. Wheatly, M.G.; Gannon, A.T. Ion Regulation in Crayfish: Freshwater Adaptations and the Problem of Molting. Am. Zoöl. 1995, 35, 49-59. [CrossRef]

50. Vijayan, K.; Diwan, A. Fluctuations in $\mathrm{Ca}, \mathrm{Mg}$ and $\mathrm{P}$ levels in the hemolymph, muscle, midgut gland and exoskeleton during the moult cycle of the Indian white prawn, Penaeus indicus (Decapoda: Penaeidae). Comp. Biochem. Physiol. Part A: Physiol. 1996, 114, 91-97. [CrossRef]

51. Zachar, J.; Zacharová, D. Potassium contractures in single muscle fibres of the crayfish. J. Physiol. 1966, 186, 596-618. [CrossRef]

52. Nędzarek, A.; Czerniejewski, P.; Tórz, A. Macro- and trace elements in Chinese mitten crabs (Eriocheir sinensis) from Szczecin Lagoon, Poland-Implications for human health. Aquac. 2019, 506, 229-237. [CrossRef]

53. Gálvez, F.; Domínguez, R.; Maggiolino, A.; Pateiro, M.; Carballo, J.; De Palo, P.; Barba, F.J.; Lorenzo, J.M. Meat Quality of Commercial Chickens Reared in Different Production Systems: Industrial, Range and Organic. Ann. Anim. Sci. 2020, $20,263-285$. [CrossRef]

54. Bjerregaard, P. Relationship between physiological condition and cadmium accumulation in Carcinus maenas (L.). Comp. Biochem. Physiol. Part A Physiol. 1991, 99, 75-83. [CrossRef]

55. Bjerregaard, P.; Depledge, M. Trace metal concentrations and contents in the tissues of the shore crab Carcinus maenas: Effects of size and tissue hydration. Mar. Biol. 2002, 141, 741-752. [CrossRef]

56. EFSA. Overview on Tolerable Upper Intake Levels as Derived by the Scientific Committee on Food (SCF) and the EFSA Panel on Dietetic Products, Nutrition and Allergies (NDA). Summary of Tolerable Upper Intake Levels—Version 4. Available online: https://www.efsa.europa.eu/sites/default/files/assets/UL_Summary_tables.pdf (accessed on 17 August 2020).

57. EFSA Panel on Dietetic Products, Nutrition and Allergies (NDA); Turck, D.; Bresson, J.-L.; Burlingame, B.; Dean, T.; FairweatherTait, S.; Heinonen, M.; Hirsch-Ernst, K.I.; Mangelsdorf, I.; McArdle, H.; et al. Dietary reference values for potassium. EFSA J. 2016, 14, e04592. [CrossRef]

58. EFSA Panel on Dietetic Products, Nutrition and Allergies (NDA). Scientific Opinion on Dietary Reference Values for magnesium. EFSA J. 2015, 13, 4186-4249. [CrossRef] 
59. EFSA Panel on Nutrition, Novel Foods and Food Allergens (NDA); Turck, D.; Castenmiller, J.; De Henauw, S.; Hirsch-Ernst, K.; Kearney, J.; Knutsen, H.K.; Maciuk, A.; Mangelsdorf, I.; McArdle, H.J.; et al. Dietary reference values for sodium. EFSA J. 2019, 17, e05778. [CrossRef]

60. EFSA Panel on Dietetic Products, Nutrition and Allergies (NDA). Scientific Opinion on Dietary Reference Values for phosphorus. EFSA J. 2015, 13, 4185-4239. [CrossRef]

61. Aguilar, F.; Autrup, H.; Barlow, S.; Castle, L.; Crebelli, R.; Dekant, W.; Gontard, N.; Gott, D.; Grilli, S.; Leclercq, C.; et al. Safety of aluminium from dietary intake-Scientific Opinion of the Panel on Food Additives, Flavourings, Processing Aids and Food Contact Materials (AFC). EFSA J. 2008, 754, 1-34. [CrossRef]

62. EFSA Panel on Dietetic Products, Nutrition and Allergies (NDA). Scientific Opinion on Dietary Reference Values for iron. EFSA J. 2015, 13. [CrossRef]

63. European Commission. European Commission Regulation No 629/2008 of 2 July 2008 amending regulation EC No $1881 / 2006$ setting maximum levels for certain contaminants in foodstuffs. Off. J. Eur. Union 2008, L173, 6-9.

64. Onnen, T.; Zebe, E. Energy metabolism in the tail muscles of the shrimp Crangon crangon during work and subsequent recovery. Comp. Biochem. Physiol. Part A Physiol. 1983, 74, 833-838. [CrossRef]

65. Dooley, P.; Crouch, P.; West, J. Free amino acids in claw muscle and haemolymph from Australian freshwater crayfish at different stages of the moult cycle. Comp. Biochem. Physiol. Part A Mol. Integr. Physiol. 2002, 131, 625-637. [CrossRef]

66. Adeyeye, E.I. Comparative quality of amino acid profiles of the girth and skin of the breast of domestic duck (Anas platyrhynchos). EC Nutr. 2018, 13, 143-155.

67. Mahan, D.C.; Shields, R.G. Essential and nonessential amino acid composition of pigs from birth to 145 kilograms of body weight, and comparison to other studies. J. Anim. Sci. 1998, 76, 513-521. [CrossRef]

68. Vopálenský, J.; Suchý, P.; Straková, E.; Šimek, F.; Macháček, M.; Herzig, I. Amino acid levels in muscle tissue of eight meat cattle breeds. Czech J. Anim. Sci. 2017, 62, 339-346. [CrossRef]

69. Mai, J.; Shetty, J.K.; Kan, T.-M.; Kinsella, J.E. Protein and amino acid composition of select freshwater fish. J. Agric. Food Chem. 1980, 28, 884-885. [CrossRef]

70. Szlinder-Richert, J.; Usydus, Z.; Malesa-Ciećwierz, M.; Polak-Juszczak, L.; Ruczyńska, W. Marine and farmed fish on the Polish market: Comparison of the nutritive value and human exposure to PCDD/Fs and other contaminants. Chemosphere 2011, 85, 1725-1733. [CrossRef]

71. Usydus, Z.; Szlinder-Richert, J.; Adamczyk, M.; Szatkowska, U. Marine and farmed fish in the Polish market: Comparison of the nutritional value. Food Chem. 2011, 126, 78-84. [CrossRef]

72. Claybrook, D.L. Nitrogen metabolism. In The Biology of Crustacea: Internal Anatomy and Physiological Regulation; Mantel, L.H., Ed.; Academic Press Inc.: New York, NY, USA, 1983; pp. 163-213.

73. Chen, Y.; Qiao, Y.; Xiao, Y.; Chen, H.; Zhao, L.; Huang, M.; Zhou, G. Differences in Physicochemical and Nutritional Properties of Breast and Thigh Meat from Crossbred Chickens, Commercial Broilers, and Spent Hens. Asian-Australas. J. Anim. Sci. 2015, 29, 855-864. [CrossRef]

74. Saadoun, A.; Cabrera, M. A review of productive parameters, nutritive value and technological characteristics of farmed nutria meat (Myocastor coypus). Meat Sci. 2019, 148, 137-149. [CrossRef]

75. Velisek, J.; Koplik, R.; Cejpek, K. The Chemistry of Food; Wiley-Blackwell: Hobokoen, NJ, USA, 2020.

76. El-Medany, S.A.; El-Reffaei, W.H.; Nada, S.A. Effect of different oils on growth performance and carcass traits in growing rabbits. J. Anim. Poult. Prod. 2013, 4, 733-745. [CrossRef]

77. Adeyeye, E.I.; Omolara, A.H. Proximate, Mineral, Vitamin Compositions, Mineral Safety Index and Mineral Ratios of the Flesh of Heterosexual Pairs of Neopetrolisthes maculatus. Sustain. Food Prod. 2018, 3, 46-62. [CrossRef]

78. Adeyeye, E.I. Simultaneous Identification and Evaluation of Amino Acid Profiles of the Male and Female Innards of Neopetrolisthes maculatus. Int. Lett. Nat. Sci. 2019, 75, 13-26. [CrossRef]

79. Haščík, P.; Pavelková, A.; Tkáčová, J.; Čuboň, J.; Kačániová, M.; Habánová, M.; Mlyneková, E. The amino acid profile of broiler chicken meat after dietary administration of bee products and probiotics. Biologia 2020, 75, 1899-1908. [CrossRef]

80. Pyz-Łukasik, R.; Paszkiewicz, W. Species Variations in the Proximate Composition, Amino Acid Profile, and Protein Quality of the Muscle Tissue of Grass Carp, Bighead Carp, Siberian Sturgeon, and Wels Catfish. J. Food Qual. 2018, 2018, 1-8. [CrossRef]

81. Munekata, P.E.S.; Pateiro, M.; Domínguez, R.; Zhou, J.; Barba, F.J.; Lorenzo, J.M. Nutritional Characterization of Sea Bass Processing By-Products. Biomol. 2020, 10, 232. [CrossRef]

82. Alonso, V.; Campo, M.D.M.; Español, S.; Roncalés, P.; Beltrán, J.A. Effect of crossbreeding and gender on meat quality and fatty acid composition in pork. Meat Sci. 2009, 81, 209-217. [CrossRef]

83. Dugan, M.E.; Vahmani, P.; Turner, T.D.; Mapiye, C.; Juárez, M.; Prieto, N.; Beaulieu, A.D.; Zijlstra, R.T.; Patience, J.F.; Aalhus, J.L. Pork as a Source of Omega-3 (n-3) Fatty Acids. J. Clin. Med. 2015, 4, 1999-2011. [CrossRef]

84. Hwang, Y.-H.; Joo, S.-T. Fatty Acid Profiles, Meat Quality, and Sensory Palatability of Grain-fed and Grass-fed Beef from Hanwoo, American, and Australian Crossbred Cattle. Food Sci. Anim. Resour. 2017, 37, 153-161. [CrossRef]

85. Jain, R.; Bronkema, S.M.; Yakah, W.; Rowntree, J.E.; Bitler, C.A.; Fenton, J.I. Seasonal differences exist in the polyunsaturated fatty acid, mineral and antioxidant content of U.S. grass-finished beef. PLoS ONE 2020, 15, e0229340. [CrossRef] 
86. Renna, M.; Brugiapaglia, A.; Zanardi, E.; Destefanis, G.; Prandini, A.; Moschini, M.; Sigolo, S.; Lussiana, C. Fatty acid profile, meat quality and flavour acceptability of beef from double-muscled Piemontese young bulls fed ground flaxseed. Ital. J. Anim. Sci. 2019, 18, 355-365. [CrossRef]

87. De Almeida, J.C.; Camargo, J.L.; Gross, J.L.; Perassolo, M.S.; Bragagnolo, N. Fatty acid composition and cholesterol content of beef and chicken meat in Southern Brazil. Rev. Bras. Cienc. Farm. 2006, 42, 109-117. [CrossRef]

88. Wołoszyn, J.; Haraf, G.; Okruszek, A.; Wereńska, M.; Goluch, Z.; Teleszko, M. Fatty acid profiles and health lipid indices in the breast muscles of local Polish goose varieties. Poult. Sci. 2020, 99, 1216-1224. [CrossRef] [PubMed]

89. Simopoulos, A.P. The importance of the ratio of omega-6/omega-3 essential fatty acids. Biomed. Pharmacother. 2002, 56, 365-379. [CrossRef]

90. Radzik-Rant, A.; Rant, W.; Rozbicka-Wieczorek, A.; Kuźnicka, E. The fatty acid composition of longissimus lumborum muscle of suckling and earlyweaned dual-purpose wool/meat lambs. Arch. Anim. Breed. 2012, 55, 285-293. [CrossRef]

91. Pascual, M.J.; Calle, E.; Blasco, A. Comparison of degrees of maturity of rabbit lines selected for different traits. World Rabbit. Sci. 2015, 23, 155-161. [CrossRef]

92. Huynh, M.D.; Kitts, D.D. Evaluating nutritional quality of pacific fish species from fatty acid signatures. Food Chem. 2009, 114, 912-918. [CrossRef]

93. Attia, Y.A.; Al-Harthi, M.A.; Korish, M.A.; Shiboob, M.M. Fatty acid and cholesterol profiles, hypocholesterolemic, atherogenic, and thrombogenic indices of broiler meat in the retail market. Lipids Heal. Dis. 2017, 16, 1-11. [CrossRef]

94. Mapiye, C.; Chimonyo, M.; Dzama, K.; Hugo, A.; Strydom, P.; Muchenje, V. Fatty acid composition of beef from Nguni steers supplemented with Acacia karroo leaf-meal. J. Food Compos. Anal. 2011, 24, 523-528. [CrossRef]

95. Nevrkla, P.; Kapelański, W.; Václavková, E.; Hadas, Z.; Cebulska, A.; Nevrkla, P. Meat Quality and Fatty Acid Profile of Pork and Backfat from an Indigenous Breed and A Commercial Hybrid of Pigs. Ann. Anim. Sci. 2017, 17, 1215-1227. [CrossRef]

96. Fernandes, C.E.; Vasconcelos, M.A.D.S.; Ribeiro, M.D.A.; Sarubbo, L.A.; Andrade, S.A.C.; Filho, A.B.D.M. Nutritional and lipid profiles in marine fish species from Brazil. Food Chem. 2014, 160, 67-71. [CrossRef] [PubMed]

97. Skałecki, P.; Florek, M.; Pyć, A.; Kaliniak-Dziura, A.; Staszowska, A. Comparison of Physicochemical Properties, Fatty Acid Composition and Mineral Contents in Common Carp (Cyprinus carpio L.) Fillet and the Native Traditional Product Carp Ham. Pol. J. Food Nutr. Sci. 2016, 66, 311-319. [CrossRef]

98. Barrento, S.; Marques, A.; Teixeira, B.; Mendes, R.; Bandarra, N.M.; Vaz-Pires, P.; Nunes, M.L. Chemical composition, cholesterol, fatty acid and amino acid in two populations of brown crab Cancer pagurus: Ecological and human health implications. J. Food Compos. Anal. 2010, 23, 716-725. [CrossRef]

99. Rødbotten, M.; Kubberød, E.; Lea, P.; Ueland, Ø. A sensory map of the meat universe. Sensory profile of meat from 15 species. Meat Sci. 2004, 68, 137-144. [CrossRef] [PubMed]

100. Sobczak, M.; Panicz, R.; Eljasik, P.; Sadowski, J.; Tórz, A.; Żochowska-Kujawska, J.; Barbosa, V.; Domingues, V.; Marques, A.; Dias, J. Quality improvement of common carp (Cyprinus carpio L.) meat fortified with n-3 PUFA. Food Chem. Toxicol. 2020, 139, 111261. [CrossRef] [PubMed]

101. Kotowicz, M.; Lachowicz, K.; Lisiecki, S.; Szczygielski, M.; Żych, A. Characteristics of common pheasant (Phasianus col-chicus) meat. Archiv. Geflugelkd. 2012, 76, 270-276.

102. Żochowska-Kujawska, J.; Sobczak, M.; Lachowicz, K. Comparison of the texture, rheological properties and myofibre characteristics of SM (semimembranosus) muscle of selected species of game animals. Pol. J. Food Nutr. Sci. 2009, 59, $243-246$.

103. Sobczak, M.; Lachowicz, K.; Gajowiecki, L.; Czarnecki, R.; Żochowska-Kujawska, J.; Klemke, A. The effect of the use of Pietrain and Duroc boars in reciprocal crossing with crossbred gilts on quality and susceptibility of two muscles of the offspring to changes induced by massage. Anim. Sci. Pap. Rep. 2006, 24, 223-230.

104. Sobczak, M.; Lachowicz, K.; Żochowska-Kujawska, J. The influence of giant fibres on utility for production of massaged products of porcine muscle longissimus dorsi. Meat Sci. 2010, 84, 638-644. [CrossRef]

105. Lachowicz, K.; Kamieniecki, H.; Gajowiecki, L.; Wójcik, J.; Szarkowski, K.; Sobczak, M.; Żochowska-Kujawska, J.; Ko-towicz, M.; Żych, A. Comparision of texture, structure of ST muscle of Black-White cattle cross breeds with Charolaise, Marchigiana, Piemontese and Chianina and their susceptibility to massaging. Pol. J. Food Nutr. Sci. 2007, 57, 63-68.

106. Hamre, K.; Bjørnevik, M.; Espe, M.; Conceição, L.E.C.; Johansen, J.; Silva, J.; Hillestad, M.; Prabhu, A.J.; Taylor, J.F.; Tocher, D.R.; et al. Dietary micronutrient composition affects fillet texture and muscle cell size in Atlantic salmon (Salmo salar). Aquac. Nutr. 2020, 26, 936-945. [CrossRef]

107. Fard, A.N.; Seidgar, M.; Azadikhah, D. The study of frozen Astacus leptodactylus tail fillet quality changes. Aquac. Aquar. Conserv. Legis. 2015, 8, 988-998.

108. Millar, S.J.; Moss, B.W.; Stevenson, M.H. The effect of ionising radiation on the colour of leg and breast of poultry meat. Meat Sci. 2000, 55, 361-370. [CrossRef]

109. Bocian, M.; Jankowiak, H.; Reszka, P.; Banaszak, S. Pork quality with special emphasis on colour and its changes during storage. J. Cent. Eur. Agric. 2018, 19, 102-113. [CrossRef]

110. Kim, T.-H.; Choi, Y.-S.; Choi, J.-H.; Han, D.-J.; Kim, H.-Y.; Lee, M.-A.; Shim, S.-Y.; Paik, H.-D.; Kim, C.-J. Physicochemical Properties and Sensory Characteristics of Semi-dried Pork Jerky with Rice Bran Fiber. Food Sci. Anim. Resour. 2010, 30, 966-974. [CrossRef] 
111. Li, X.; Zhang, D.-Q.; Ijaz, M.; Tian, G.; Chen, J.; Du, M. Colour characteristics of beef longissimus thoracis during early $72 \mathrm{~h}$ postmortem. Meat Sci. 2020, 108245, 108245. [CrossRef] [PubMed]

112. Sales, L.A.; Rodrigues, L.M.; Silva, D.R.G.; Fontes, P.R.; Filho, R.D.A.T.; Ramos, A.D.L.S.; Ramos, E.M. Effect of freezing/irradiation/thawing processes and subsequent aging on tenderness, color, and oxidative properties of beef. Meat Sci. 2020, 163, 108078. [CrossRef]

113. Skewes, O.; Cádiz, P.; Merino, V.; Islas, A.; Morales, R. Muscle fibre characteristics, enzyme activity and meat colour of wild boar (Sus scrofa s. L.) muscle with $2 \mathrm{n}=36$ compared to those of phenotypically similar crossbreeds $(2 \mathrm{n}=37$ and $2 \mathrm{n}=38)$. Meat Sci. 2014, 98, 272-278. [CrossRef]

114. Levine, R.J.C.; Davidheiser, S.; Kelly, A.M.; Kensler, R.W.; Leferovich, J.; Davies, R.E. Fibre types inLimulus telson muscles: Morphology and histochemistry. J. Muscle Res. Cell Motil. 1989, 10, 53-66. [CrossRef]

115. Periago-Castón, M.J.; Ayala, M.; Albors, O.L.; Abdel, I.; Martínez, C.; García-Alcázar, A.; Ros, G.; Gil, F. Muscle cellularity and flesh quality of wild and farmed sea bass, Dicentrarchus labrax L. Aquaculture 2005, 249, 175-188. [CrossRef]

116. Panicz, R.; Sadowski, J.; Sobczak, M.; Żochowska-Kujawska, J. Effect of feeding various levels of poultry by-product meal on the blood parameters, filet composition and structure of female tenches (Tinca tinca). Aquac. Res. 2017, 48, 5373-5384. [CrossRef]

117. Cheng, H.; Song, S.; Jung, E.-Y.; Jeong, J.-Y.; Joo, S.-T.; Kim, G.-D. Comparison of beef quality influenced by freeze-thawing among different beef cuts having different muscle fiber characteristics. Meat Sci. 2020, 169, 108206. [CrossRef] [PubMed]

118. Smith, D.P.; Fletcher, D.L. Chicken Breast Muscle Fiber Type and Diameter as Influenced by Age and Intramuscular Location. Poult. Sci. 1988, 67, 908-913. [CrossRef] [PubMed]

119. Kokoszyński, D.; Saleh, M.; Bernacki, Z.; Kotowicz, M.; Sobczak, M.; Żochowska-Kujawska, J.; Stęczny, K. Digestive tract morphometry and breast muscle microstructure in spent breeder ducks maintainedin a conservation programme of genetic resources. Arch. Anim. Breed. 2018, 61, 373-378. [CrossRef]

120. Nollet, L.M.L.; Boylston, T.; Feng, C.; Coggins, P.; Hydlig, G.; McKee, L.H.; Kerth, C. Handbook of Meat, Poultry and Seafood Quality; John Wiley \& Sons: Hoboken, NJ, USA, 2012. 